経営史 学

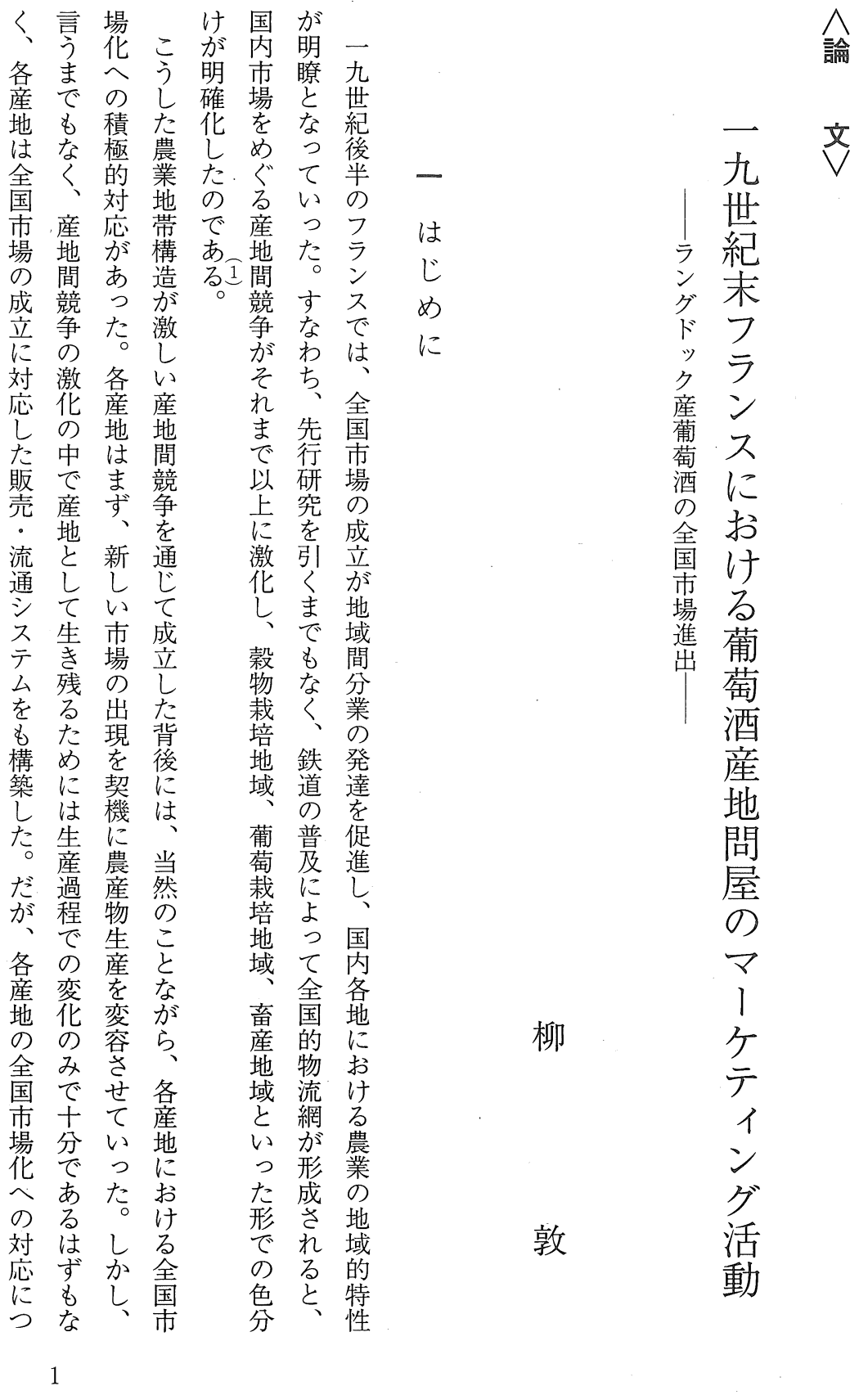




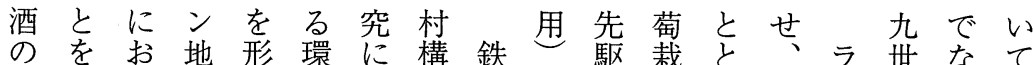
販つけ方成境よ造道葡者培もフ

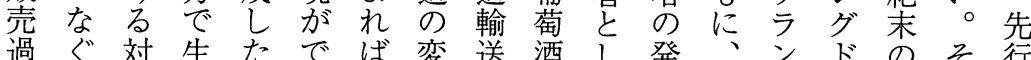

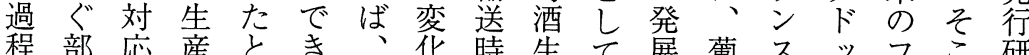
を分がささ文に代産有は萄第クラで究 等の等 れ が量つが時名、栽—地ン 、は 閑 解.閑たてりのい到代な鉄培の方 に明視葡い、葡て来を華道に葡つで稿産 付はさ萄る同萄はし開イ時適萄が展苚 全机酒。地酒、てい代し酒!開はに

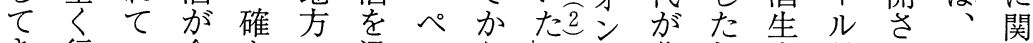
き行い全かの迅ッらしが幕気産県れて心 たわる国に葡速シののそを候地尔た われ点の、萄に工ラでの開的とエ販ン集 けてに消こ栽輸、ンああ著け条な売ス中 でい問費の培送ガグる書る件つ、有さ

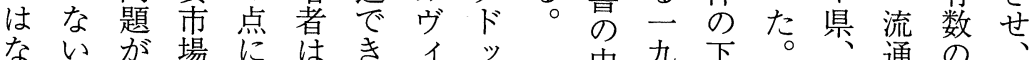

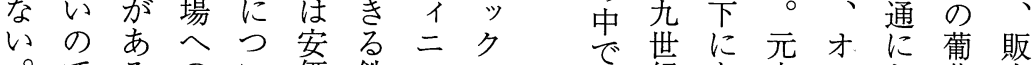
○でろのい価鉄ヨ・書紀あ来!㨚㸿

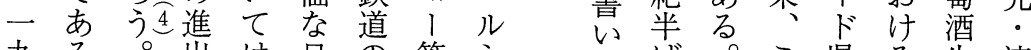
九る。出は旦の等 シ て崶る生流 世。市に、常出を当的またの仝全通

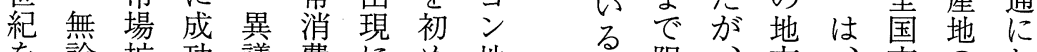
を論拡功議費にめ地によ限方市市のお 対尖しを角よと方方ら近は一場一け 象ラにた差葡つにに隣隣九化つる とンよこ萄てでおた接世施で対

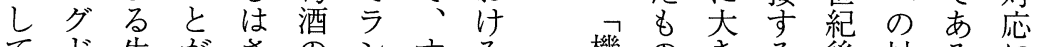
てド生がさのンする機のきる後対るに 他ッ産鉄む大グで葡関になル半応南関

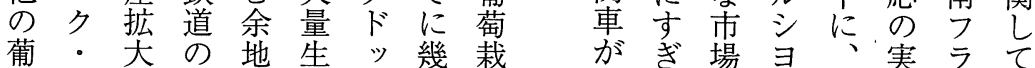

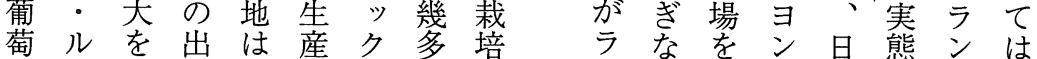

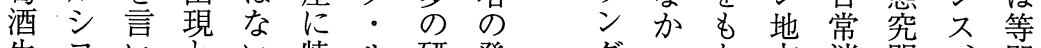
生ヨいとい特ル研発当づった 方消琞、䦥

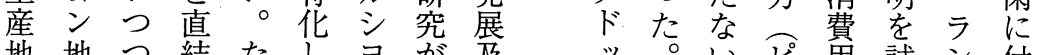

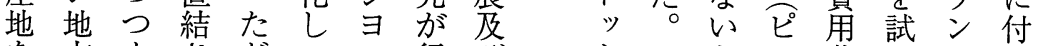

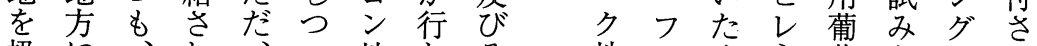

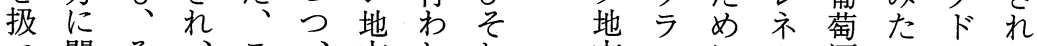
つ関そ、方れれ方ンにに酒いッて

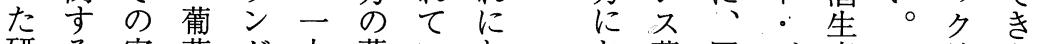
研る実萄グ大葡いと就葡同ゾ産地た

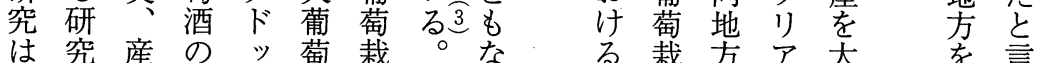

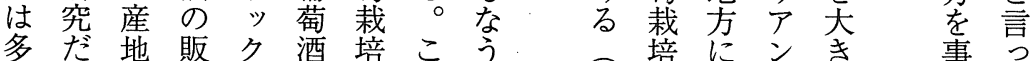

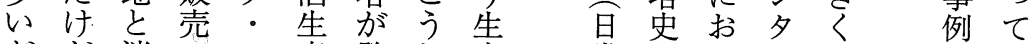
がが消: ル産発し産常研けル発にも

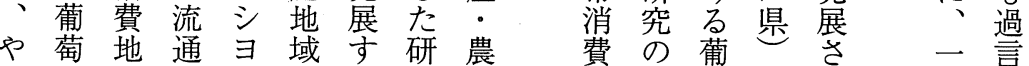


経 営史 学

屋そ接ない態先

ザこずこの行

イでさとも研

ス、わ○の究

の本る无をに

文稿閣ち示お

エは仲ん資て

口 部 介ラ蒛

分業ンほ酒

県的者グとの

文なにドん販

書二関 ッど売

館 つす 方現過

にのる 地 存 程

残資資方しの

る料料たて 検

破をのけい討

産つ発のな が

文き掘こい炎

書あとと 落

でわなでらし

あせるはでて

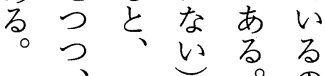

産層はラは

地困モン、

問難 Iグ資

屋でラド料

のあンッ的

実るがク制

態。適地 約

に確方に

迫にによ

り指おる

た摘けと

い 乙 る こ

二 い場 が

の が党き

資、資い

料葡料。

と萄収流

は酒 集 通

産 琉 容 機

地閣直晹
品酒同流にす屋は

のレ地と通焦るがこり

全と方こ過点中果う生

国はのろ程をでしし産

市性葡での当、たた者

場格萄、問て ラ役研㤎

二 形 が酒ラ題、ン割究主

成異はンをそグを状た 分のな消グ検のド具況る 分在つ費ド討マッ体を対 析りて市ッし1 ク 的ふ象 資方い場ク、ケ産にまと

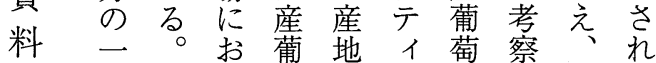
端こい萄問ン酒守本 をのて 酒屋グがる稿 葡 示点科がの活いこは萄 す で売安歴動かと、酒 も、り価史のにを一の のラさな的実全課九販 とンれ日使態国題世売 しグて 常命に進と紀過 てドい消を迫出し末末程 もッた費明りをたラの 位ク大向らた果いン検 置産衆けかいた。グ討 付葡商葡に。しまは け萄品萄し次た。ずッ今 ら酒で酒たいの、ク後 れのあでいでか一地の よ流りあ。、方方課 う通、全全世に題 過ボた点市国紀お と にドは場場ばるれ 関、重にと以葡て すや定産降萄い。 るブて 着地全酒る可

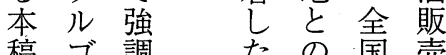

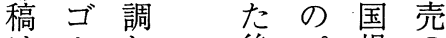
は Iし後パ規の 、ニ のイ 模実 大ュお ラプで態

衆なか役の 消どなグで物と 費のけドあ流り 用いれッつがわ 農わば学たけ 産ゆな産産い坣 物るる葡地に産 - ᄀま萄問発地 商銘以酒屋展問 


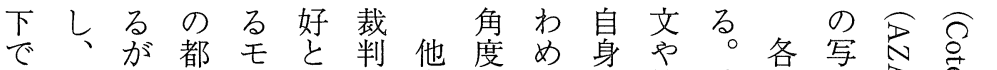

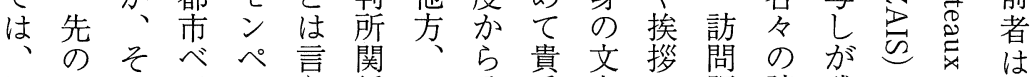

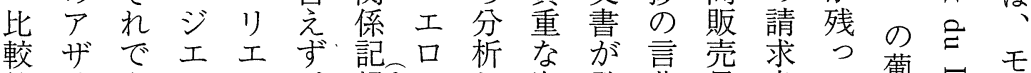

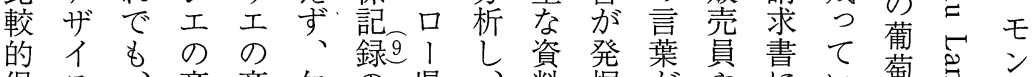

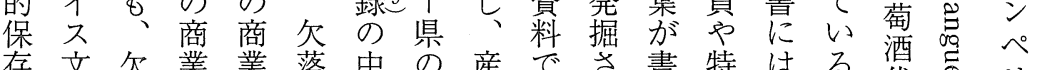
存文欠業業落中の産でさ書特は昰洒怘り

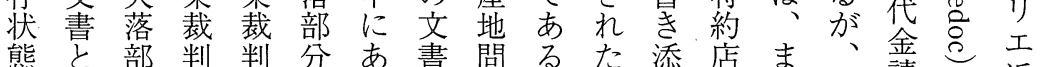

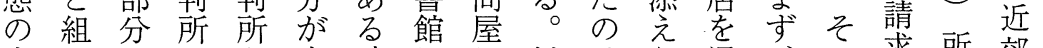
良みはのが少破にに以は通、の求所郊 い合多文扱な産は卡机じ二う書蔵の 破わい書吕つく文商るで現ててこちののモ 産せ。老たな書業葡は在いの買判写手! 書るま利破い吕関萄っのる注買読で書ラ 類こた用産。見係酒ことこ文手可できン

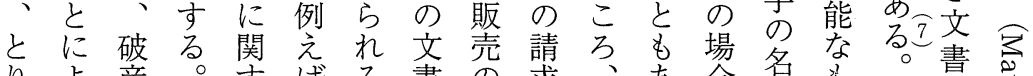

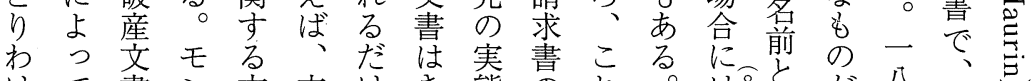

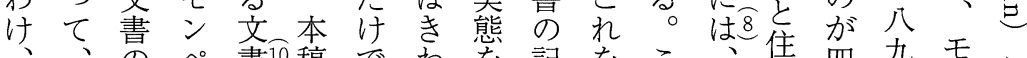

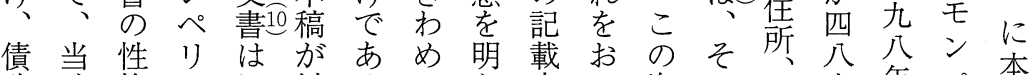
務時格工ほ対るてら货い資のこ六年ぺ本 者の上のと象。少か容て料旨三枚十り部

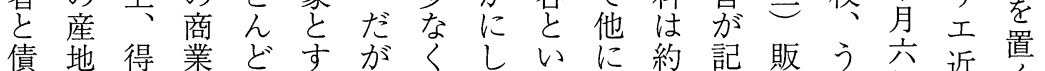

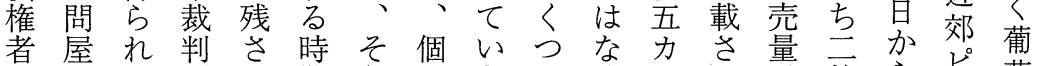

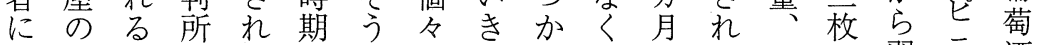
関あデ関てにしのたの、分て引は翌二酒 すり1係いつた商い請産のいき書年中生 る方多ない破店。求地貶る価簡言ン 産

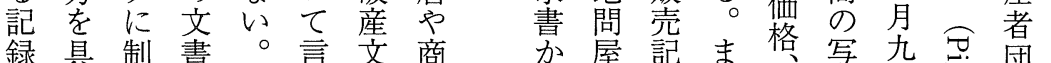

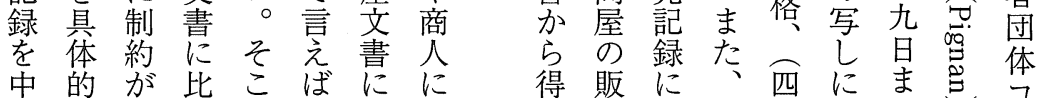

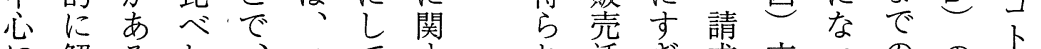
に解るれ、工て亦活き求支つのの! 利明こば本口もるるる動な書払て時産! 用でと保稿! 資付のいにいい期地デ

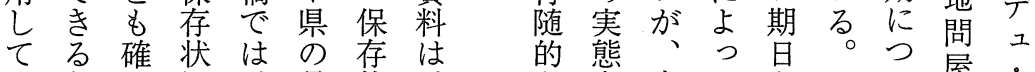

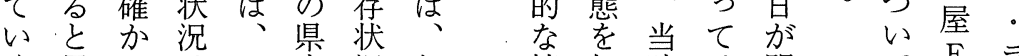
く思では工庁況わ情知時は明て $F$ ラ わあ良口所はず報るの記約・ン

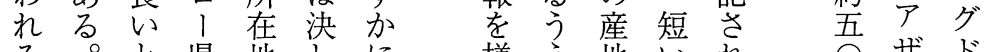
る。と県地しに様え地いれ知吾げド

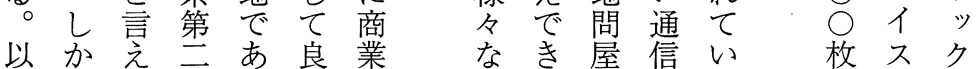


経 営史 学

表 1 葡萄酒消費量 (年平均: 万ヘクトリットル)

\begin{tabular}{cccc}
\hline & $\mathrm{A}$ 国内消費量 & $\mathrm{B}$ 市場消費量 & $\mathrm{C}$ 自家消費量 $(\mathrm{A}-\mathrm{B})$ \\
\hline $1840-49$ & 3,242 & 1,754 & 1,438 \\
$1850-59$ & 2,917 & 1,677 & 1,240 \\
$1860-69$ & 4,394 & 2,355 & 2,039 \\
$1870-79$ & 5,367 & 2,763 & 2,604 \\
$1880-89$ & 3,683 & 2,739 & 944 \\
$1890-99$ & 3,998 & 3,196 & 802 \\
$1900-09$ & 5,848 & 4,435 & 1,413 \\
\hline
\end{tabular}

(出典) Annuaire Statistique de la France, 1914-15, pp.110-111より計 算して作成.

増い三一ち○れ

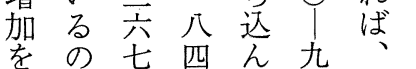

をで方四で苍葡

○市降に

初 ま

めず

には、

生 利

産用三

量 可

衣能葡

輸な萄

量全酒

と統熊

の計 費

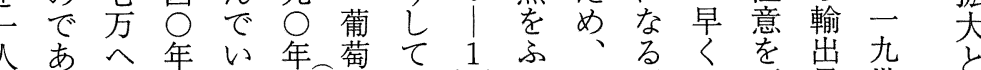

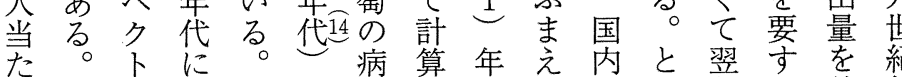

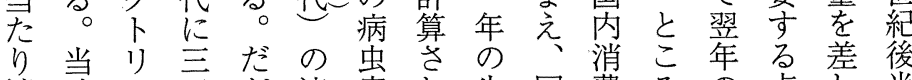

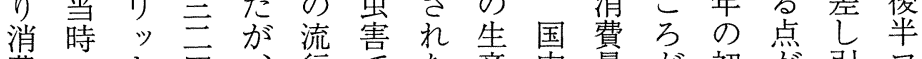

費のト西、行号た産内量が初㤎

量フル三国にあ国量消の、めあいう

のラ、方呙ょる内量費推統でるてンク

増ン一へ消つオ消 $\mathrm{t}$ 量計計あ。推 ス。

加ス九ク費てイ費年をに上る秋計のル

とは○ト量生デ量の次あで。にさ葡シ

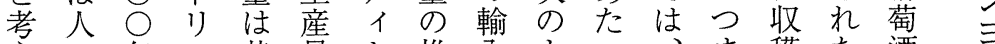

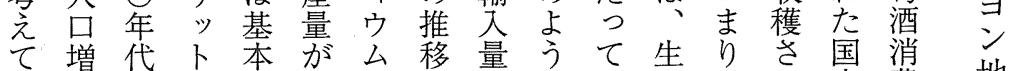

よ加にル的大つ竞には産、市費地

いが五たにき二示 $\mathrm{t}$ 計、量葡た消市方

た停八う拡く八し年算生が萄葡費場

ろ滞四た大減五たの夺産収酒萄量を

う几八国傾少○の輸る量穫がかの概

て万内向し年が出。を市ら動観

扮へ消にた代表量一行場葡きす

りク費あ時年1 1 年わに萄をる

、卜量っ期やの $\mathrm{t}$ ず出酒見作

こリはたにフA 年らた回がよ業

うッ、とは、欄の年るでうか

しト一自、口で国なにのき。ら

たル八て国クあ内記はあた始

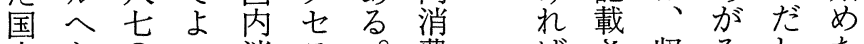

内と○い消ラ。費ばさ収るした

消増年た費二こ量な热檴のこい。

費妿帒ろ量云れに

のて五。落八ょ。檤る。年一場 
第27巻 第 1 号

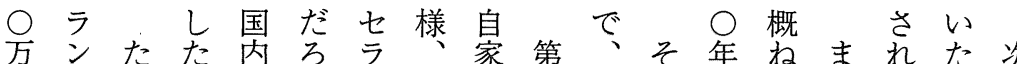

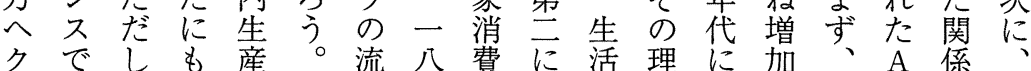

卜は、加量さ行七量、水㕣四傾市欄で国

リ、右かがらに○自準と四向場の 、内

ッ一のわ二によ年推家一し三に消国市消

八刀二ら九移消般て五あ費内場費

ル七八ず○一てまを費のはへう量消消量

分○七、○九生で見の上た費費を

の年 $\bigcirc$ 自年 $○$ はる

葡代年家代 $た$ 基と部がーリ言いが場

萄ま代消に年葡本、が消にッつてら関消

酒での費五代萄的先市費、トてはこ专

がア自量四の酒にの場者鉄ルよ增市のる 量

蒸ル家は九自不増市消の道ま蒲市統と

留コ消そ声家足加場費購 の普増う萄場計自

れル量にへ費中向費移力昂加。病費、消

て生に見ク量でに量行をにし一虫量夕費 い産は合卜が生あとし引よて害をが量

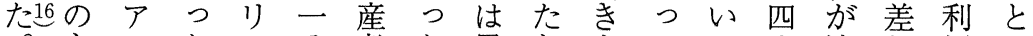
主ルたッ八者た異と上てる○流し用に た原コ回卜七古がな考げ、の年行引可わ た料、復ル○自、るえたよで代しき能け

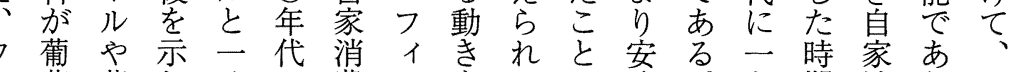

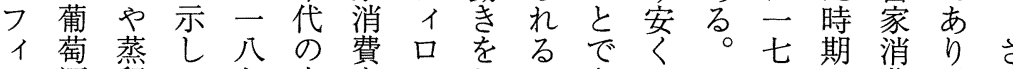
口酒留て七水をクしこあょ吾に費、ら クで酒い○準抑セてとる留り 四は量そに セあのな年の制ラいで。手方伸をれ詳

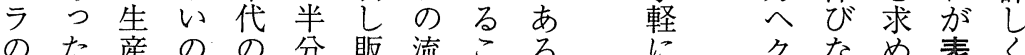

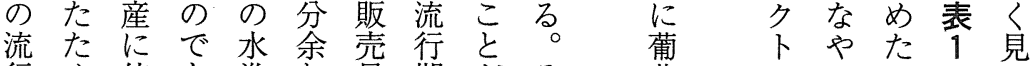

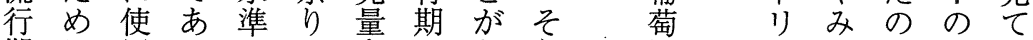

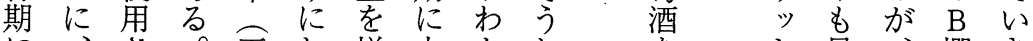
に、さ。五し 増大かかし見、䑌き

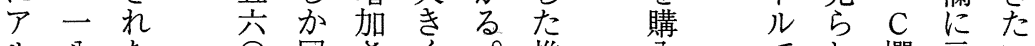

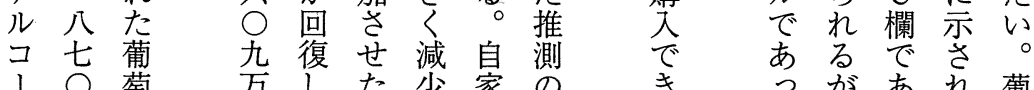
ル年酒へな方な少家

生代量 ク吕とた費拠

産に昌っに。量は

のお含りたよこは左

中いま点るれ市の

心てれトにと場通

がはて注考、消り

甜、以目えフ費で

菜約るをしてイ量あ

に四っ 移 $フ$ 回た よ

瓄

るた、るて萄

環市一。い酒

境場九 るが

が消世流

で 費 紀 ま通

き量後 た税

つ先課

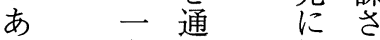

る九芯推れ

中 
経 営史学

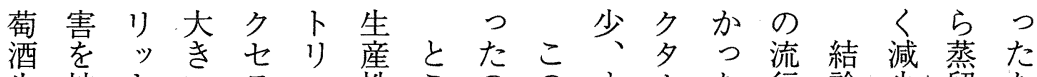

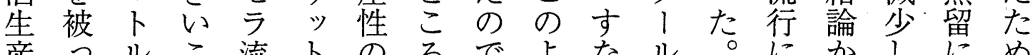
産っルこ流卜のろでよなル。にかしに

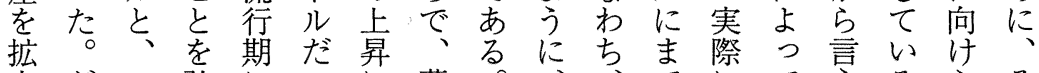

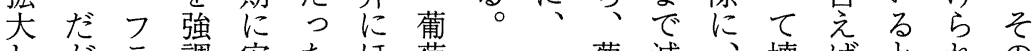
しがラ調安たほ萄—葡減、壊ばとれの て、ンし価がか栽九萄少一滅、言た後 い葡スてな、な培世酒し八しこ藏に つ萄第お拈一ら面紀自た吕七たのよ萄お た栽—き常九な積後家。四葡よう酒け の培のた消○いの半消三年萄う。量る で地水い費○。減に費吾に栽なフ葡 あを準。角年実少市者年云培自イ差萄 る19早を同葡代際に場の間西地家口酒 期誇地萄に年消減に六の消ク引か にっ方酒は一古費少、方再費七いら 再てに生言八か量を約へ建量ラたの 建い扔産三六わ的言》は流三蒸 すたけに・○ら増も门多多減行三留 るのる特七年ず加な \% l 額少期 ○量 とで一化へ代全傾いのルのをに○は とあへしクの国悡、減で費も何万わ もる18ク一ト一生に市少あ角たらへず に。名的産、場をつをらかクか 確 1 産 $ッ$ 量 多少儿地卜多量 収にあとル1 量市なにルイ 品ラりつまあロ 種ンのたでたク のグ生ラ上りセ 導ド産ン昇のラ 入ッ量グし葡 流 をクはドて・萄行 図・少小酒後 りルークる生に

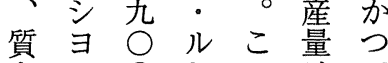
よシ○シのはて

$り$ 地 年 $\exists$ 点 全 も方代之究国水 量もに地は平準 老フ方均に 重々四のと王回 視口七果々三復

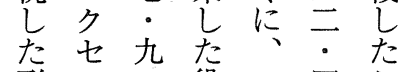
形今役 ᄀ四こ

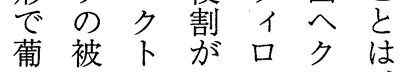
つ消見た必しの卜な た費たフ要た変り程 。者のラ芝最化”度 葡・索でンし大古卜に

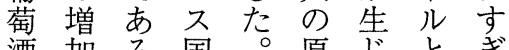
酒加る国。原飞と到 生を。呙こ因た比な 産生このの性どい 者几う葡た匍考て。

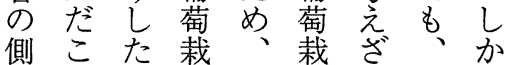

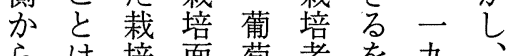
らは培面萄著を九 言明面積栽学充 0 -

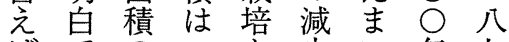
壮穴合妿少い年七 声減八弓飞。代 0 市る少九脱南の年 場。为九落る。自代

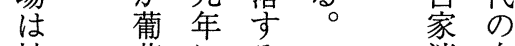

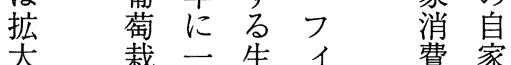
傾坴七産口亶消 向者一者 告費

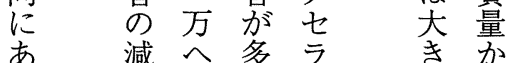


総酒 ○で 内酒ドてっ少壊二両か

重量年確結はで生生ッこてし滅年県う他 量がのか果、は産産クのいた包しには、の

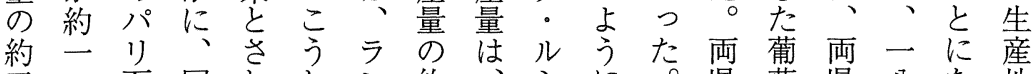
二一万同れしン約、シに。県萄県八な地 ○一国地てたグ半一ヨ、の截で七る。 \%万博方いラド分八ンフ葡培二 がトに内るンッを帝、萄地六年最常 輸ンエで。グク占 ○可栽の・代も消 送と口生しド・め年日ク培再八初典費 樽書 ! 産かッルる代常セ地建方頭型角

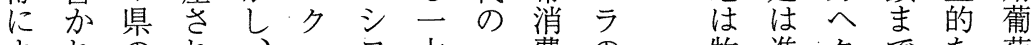

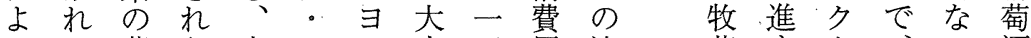
つて葡た産ルン生五角流草ま多、の酒 てい萄葡地シ, 産産 $\bigcirc$ 葡行地ず、パが生 占石酒萄か、葡地 め。酒らン萄と方酒多転一へ向シは らも出の消地酒なへの額換八全けャ れつ展大費方はるク方学艺国のララ

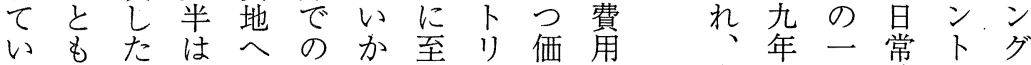
た、際鉄、の葡に薄に格を有に一消両ド とこの道流萄消た会卜に要名葡\%費県ッ

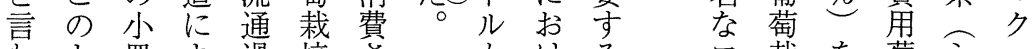
わト冊よ過培省加けるる栽を葡シ 。 れン子つ程のれるる葡薄誇萄ヤル る数にての発て 一優萄にヤ面つ酒ラシ のには他考展い位栽、ッ積て生ンシ

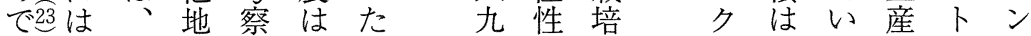
輸一方全の怔地地五た地県地 こ送八へ尔国た年大の方・のと方 の樽九発い市乃にい再尼でしシか

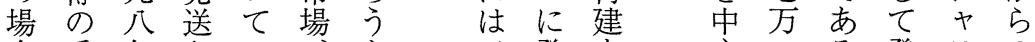
合重年さい方発を学 心方発ラの

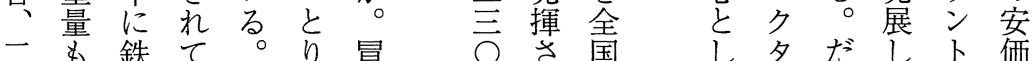

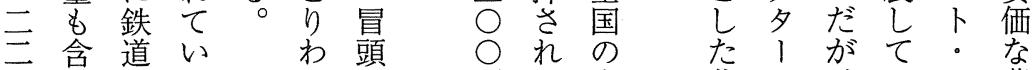

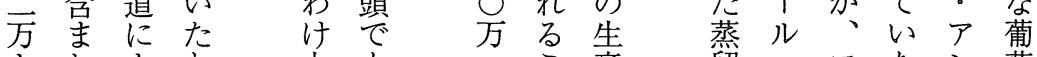

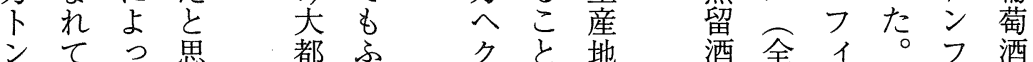

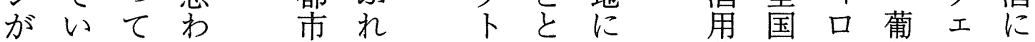
樽る県れ市た 少な強葡のク萄り第 のと外る 場よ萄声セ栽工さ 重考に方少たた栽・ラ培的

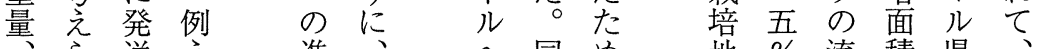

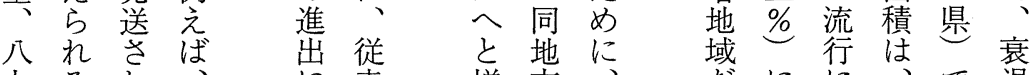

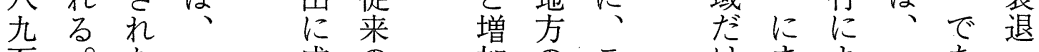
万。 成の一妿のラ た

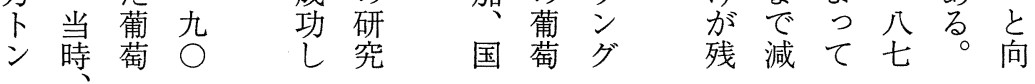


経 営史 学

表 2 萄葡酒消費上位 7 県 (1900年)

\begin{tabular}{lcc}
\hline & $\begin{array}{c}\text { 県内消費量 } \\
\text { (万ヘトル) }\end{array}$ & $\begin{array}{c}\text { 県民一人あたり } \\
\text { ヘクトット }\end{array}$ \\
\hline パリ & 537 & 2.11 \\
セーヌ県 & 201 & 2.50 \\
ローヌ県 & 139 & 1.65 \\
ジロンド県 & 129 & 1.59 \\
プーシュ・デュ・ローヌ県 & 103 & 1.53 \\
ロワール県 & 102 & 1.63 \\
セーヌ・エ・オワーズ県 & 100 & 1.55 \\
全 国 & 3,596 & 0.94 \\
\hline
\end{tabular}

り九 が

わ七葡

け年 萄

アの 酒

ルエの

ジ口重

工 量

リ県と

アのな

加葡り

ら萄

の 酒 葡

葡生萄

萄産酒

(出典) Annuaire Statistique de la France, 1900, pp. 166-167.

酒量一 がはト

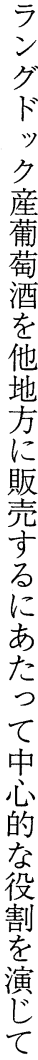

地の以デれ量マ○大道在二九シ 問葡下、て のル○他部にし 屋萄で多い半七年方分よて○五一 の酒はもた分イの方名い方 マの、存のを工葡各鉄県たへへへ ” 流個在か賄な萄県道外発ククク ク四々れ々しは年ゔ酒のに発送卜卜卜 テをのな先ラの市葡よ送可りリ少

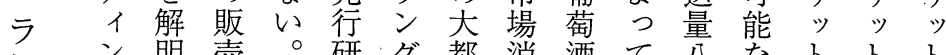
ンン明売。研・グ都消酒て瓜なト グ グし事個究ド市費市県九葡ルル、

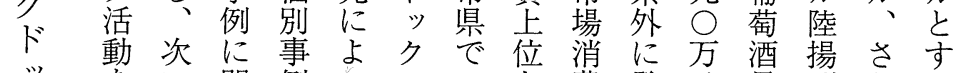
”をい関例っ・の亚登は量任られ 方ク明ですののて葡県量送そはさにば

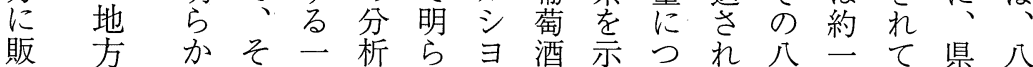
売のにの次をかシ消しいて

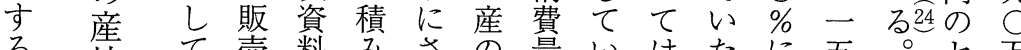
る地て売料みささの量いはたに五。セ方 に問い過を重机葡がる統と及方しッへ あ閏き程使ねて萄多が計考びへた卜ク

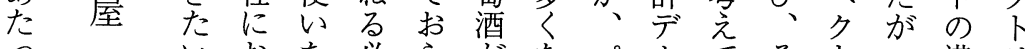

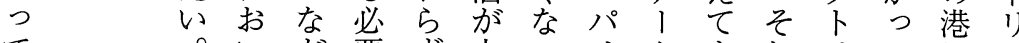
いが要ず大つリ多よれリてにッ てら务、都て地がい故ッ、はト 重、あま市い域存だ、ト一ール 要生るた地るや在ろ生ル八八と な産た域。少主産と厹九な 意地ろそにた寻る。劣概八公る 義かう扎染ン。和算年年。 をら。をの、、表た芯にに他 担消そ直よ全ボ 2 葡き県海方 た地で費に罢代は萄方芮外一 産地尔流産! 公酒鉄存々八 
設 産 当

実 備 者 時 産 (1)

際をの、地貯

に準 倉口問

備 に入屋

産 寸 貯 れの

地る 蔵 屋 貯

問必 続 $尺$ 蔵 輸

至㤎綂号僙樽

贓無必导に

能つ要をい

力たにをて

との 応介は

販でじし

売あて生部

量る。出苼 の

比年者産

るい

と く葡萄方

きが酒う

な 一をか

隔般入が

た 的手い

り でし 知

があてる

あついこ

る。た た

例こ地で

えの問き

ば、な屋る

一

八当販 貯

七時売 蔵

五契 倉

年産 約 は

+ 地 非

二 問 成 常

月 屋立に

に は後小

破大 \& 規

産規・葡 模

乙 模 萄 で

た な酒あ

ベ貯はつ

シ 蔵生た

表 3 産地問屋数の推移

\begin{tabular}{rrrrrc}
\hline & 1850 & 1872 & 1898 & 1910 & 1925 \\
\hline モンペリエ & 15 & 126 & 174 & 124 & 72 \\
ベ ジ エ & 14 & 76 & $159^{*}$ & 106 & 53 \\
\hline
\end{tabular}

(出典) 各年のAnnuaires de l'Hérault. *は1906年.

い 以 モ か 産 苨て 屋大 下ぺて問両県がく九のが

でリが屋市内掲増世地産

は土産のにの載加紀方地

、に地数共葡さ半外内

こ七問が通萄れたば販の

う屋増し酒てこに売問

し、の加て商おと鉄が屋

たべ最をい業り、は道主で

最 ジ盛続る中、、時流あ

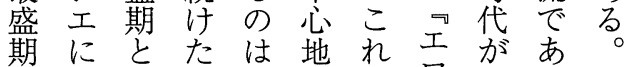

の五言点、壬は幕つ他

産三莒鉄ン同息をた地

地とてあ道ぺ県県明と方

問なよる建りの年け言の

屋るい文設土産鑑るつう問

に。で産をと地学とて 屋

る あ地契べ問かとよに

い 万問機 $シ 3$ 屋 5 \&

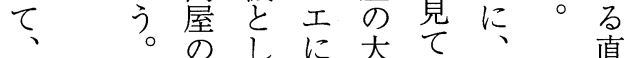

そ そ数飞接

の の市、いをれ地市

設後らラて カ

備高 ン産バっ ヘ

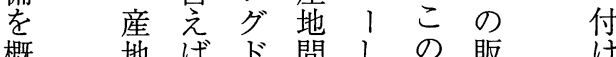

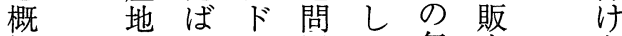

観問、ッ屋て 年売文

し 屋一夕数い鑑をを行

た 数九地のるに自わ

後は世方推とは的证

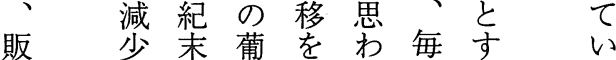

売、方萄示れ年る

先、ら酒しる到、葡加

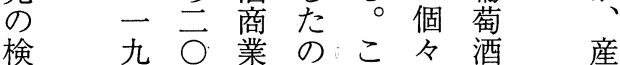

討 世 は がれの問地

を五紀 繁表を葡屋問

行年初栄 3 利萄の 屋

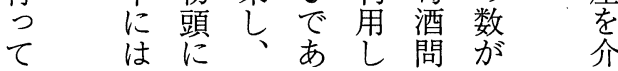


経 営 史 学

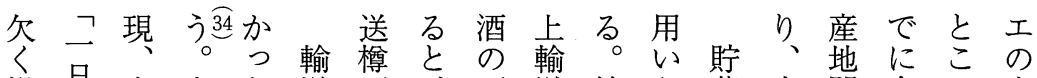
場㫔産また送祡禹送輸ら蔵小問合乃産

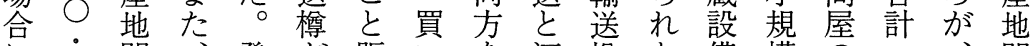

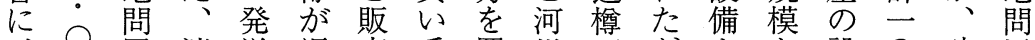
五屋消送返売手買川街よな設○破屋 賃五亡 費し却さ吼交とけり産立四産七

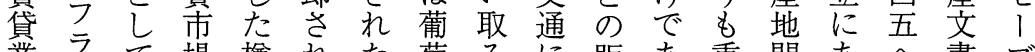
業ラて場樽れた萄るにに販あ重問あへ書ブ 者では側㚙る事酒わ頼筅り要屋たクにに

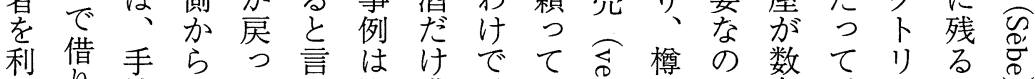
利昔 手

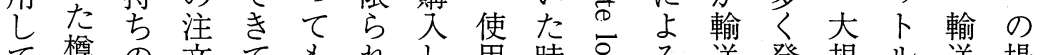

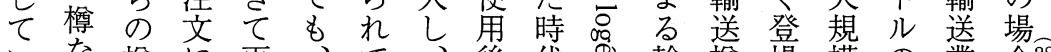

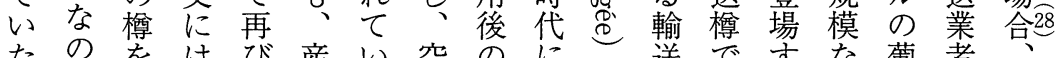

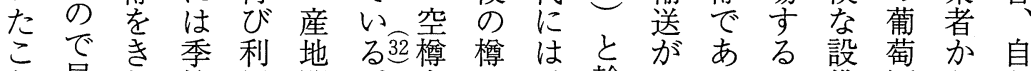
と早り節用問。孚は、輸二るこ備酒らら が急つ的可屋返買も送般。とはをのの わにめ変能は却以つ樽的当と必様請葡 加送、動に業吉手ぱに葆な要々 求萄

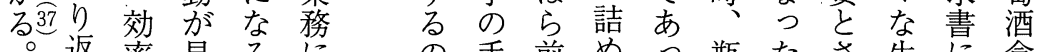
○返率見るに手前めつ瓶たさ生に倉

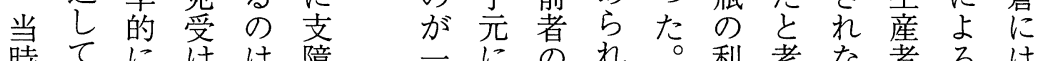
時てにけは障 頂 樽ら早を

約きをれくき 五た利る殁てた - い用。三さ 五レ でし カ ぬ

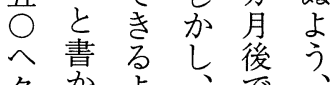
クかる、集

卜れうあ相

リてに八り䒛当

ッいな八数

トるつ。返の

ルもた句年却輸

のの代の送

樽がアに遅樽 のあザ入れを 価りイるも準 格、スとし備 㤎手の樽ばし 吾ち 持請 の 賃ばな なら 求吾貸だ い樽の業つば しに中者たな 四こに㠰とら 二航残方た检用考な者るは 般残方た樽用之葡方令々、

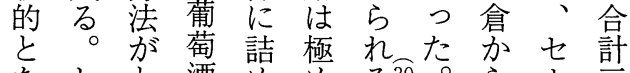

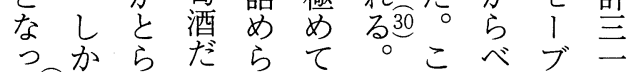

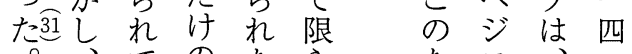

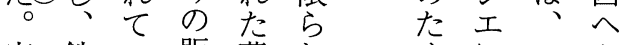
実鉄い敗葡れ め、に一ク 際道た売萄て 薄八榑 にと酒い葡ば七り いつ过のた萄さ五ッ アうま酒せ販。年卜 ザ安り、管一商て 六ル イ価、罧に部業い月分 スで買泀のる二の

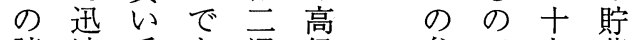
請速手あ通級参で九蔵 求なはるり葡

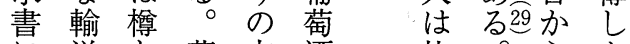
に送と荷方酒比号加 扮手々馬法や較こ十も い段の車吕サ 的のてが も普のよめ易う方 輸卞葡陸 れ に 
第27巻 第 1 号

図１アアザイスの販売先（ヘクトリットル）

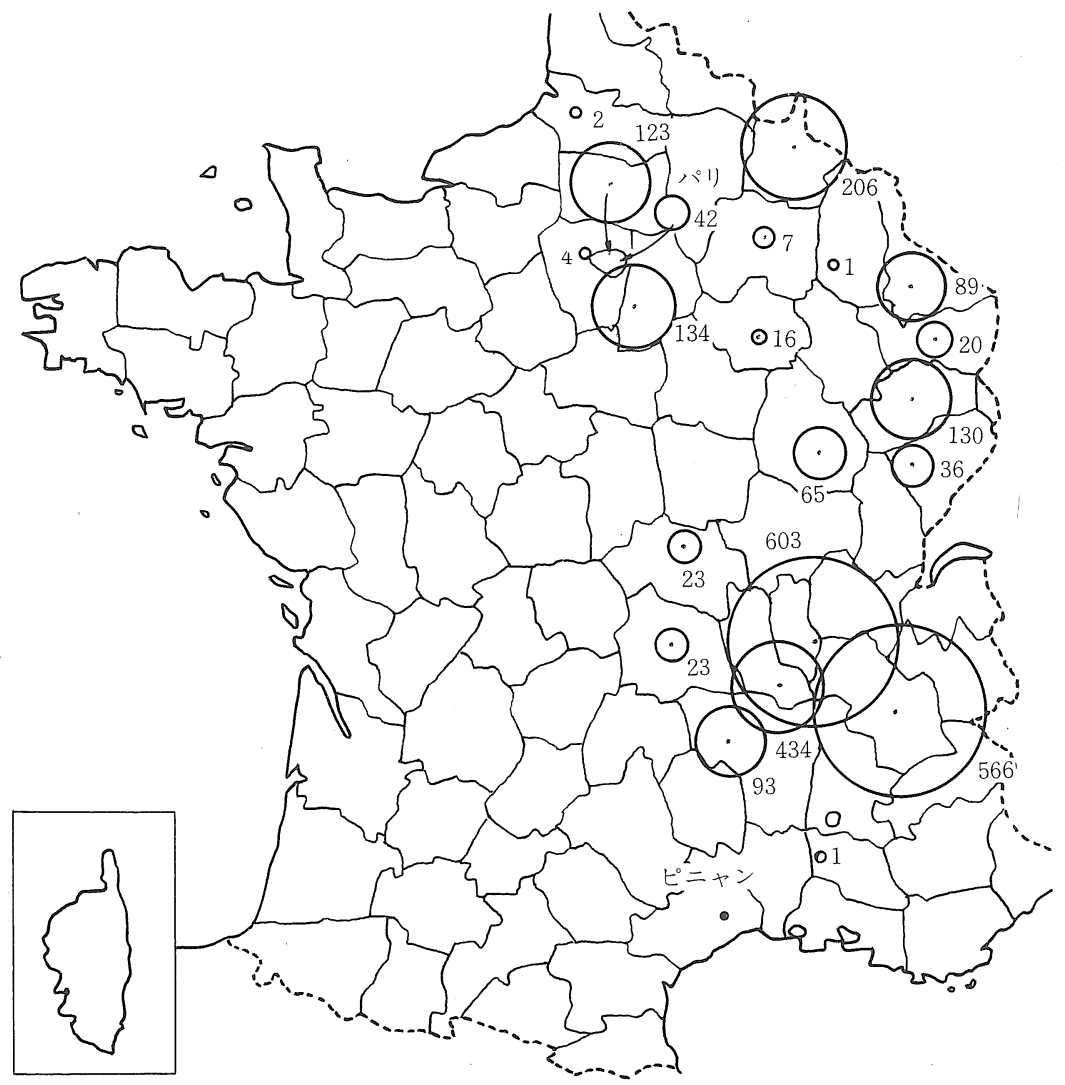

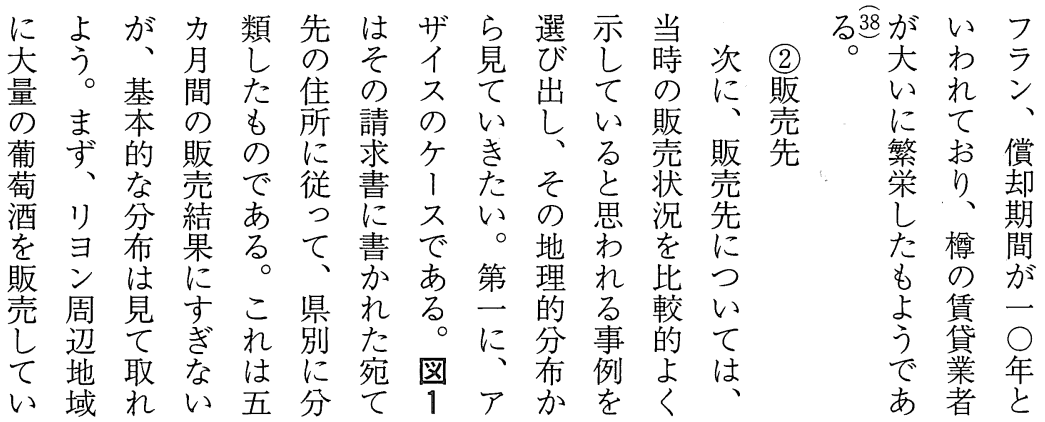


経 営史 学

㘣 2 産地問屋マス兄弟の販売先（販売件数：総数199件）

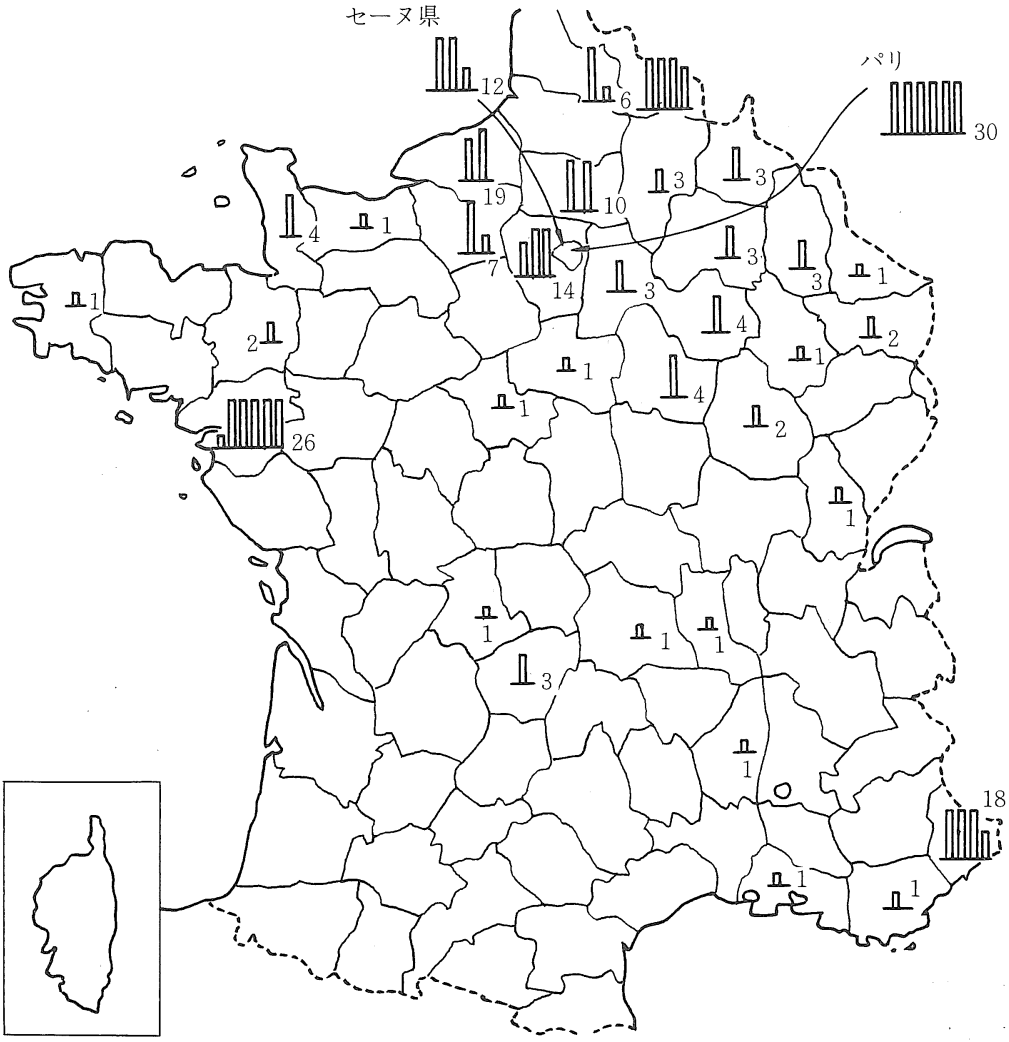

(出典) A.D.H. , 2-U-47, n 177 .

か先時に 2 理債肎た な゚リのへへる

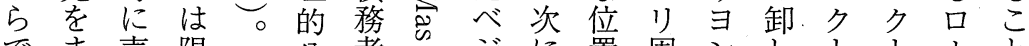
でま売限こ分者きジに置周ンしトトはと あと掛界の布名空エ、を辺注問リリヌが るめ金が場を簿㭆の一占もど屋ッッ県わ

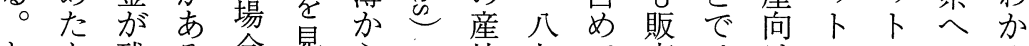

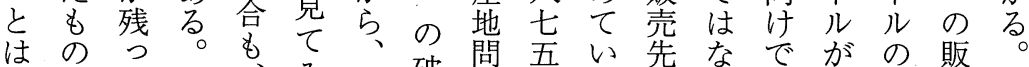

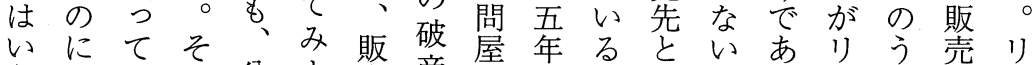
えすいれ分よ筅産交に。しにる当ち量当

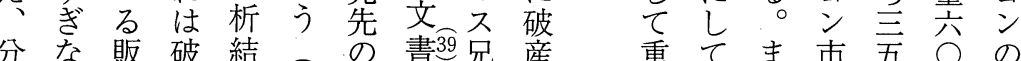

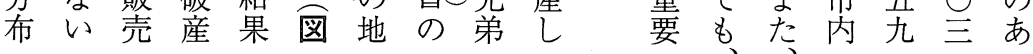


第27巻 第 1 号

売ルのて の で 表 4 アザイスの販売先

こなに販い販は

れのす売る売な

にでぎ量。がい

対あなは特占。

しる。

（1898年10月 6 日-1899年 3 月 9 日）

\begin{tabular}{ccc}
\hline & 販売量 $($ リットル $)$ & 販売件数 \\
\hline 卸し問屋 & 144,022 & 27 \\
小 売 商 & 16,226 & 69 \\
消 費 者 & 75,373 & 373 \\
合 計 & 235,621 & 469 \\
\hline
\end{tabular}

産地六 農 割 イ

問 一ク部㤎の

九卜で大 販

セ屋 ○リはき売売 販う買で

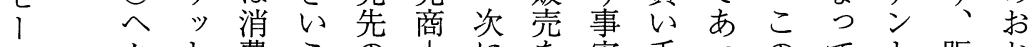

ブクト費このうにを実手つのてト販お

がトル者と構 消、主を索なるいの売よ

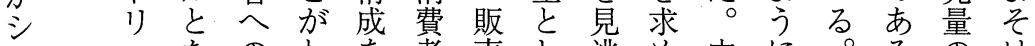

ヤッなのわを者売し逃め中に。るのは

ラ卜つ直か示と先な省てに、多う

ンルて 接る。しいのがわいは産り寡か

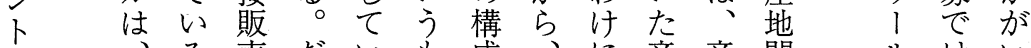

ン、る䈍だいも成、に産問いい

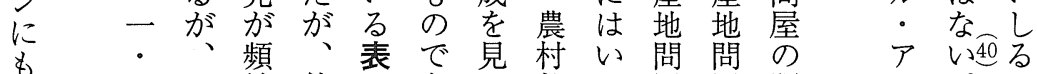

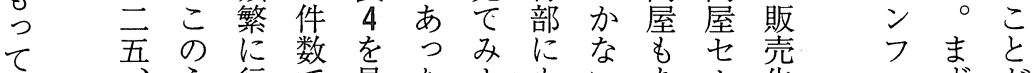

いた 二 ち わ

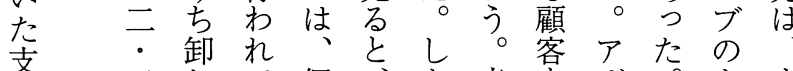

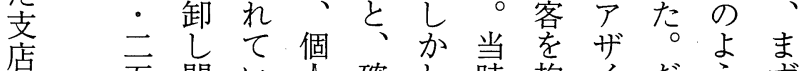

で五問い人確し時抱イだうず

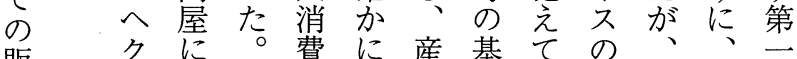

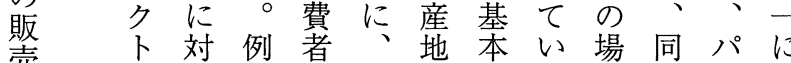

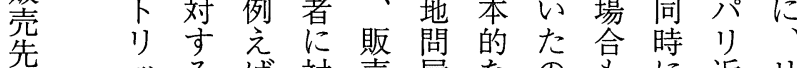

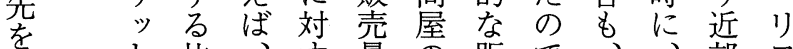

見卜比、す 量 の販で、、郊当

るル較先る の販売あマ農にン

と の的の小点売経る

樽大図口等路。兄部店パ

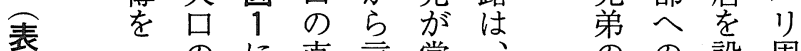

衣 二 の に 直 言常市 の の 設 周

参、々 販よ接 れ に産場販け辺

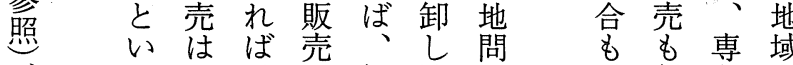

つ—、が卸問屋、行年な

個た六ア非し屋】和パど

人形へル常問で卸消れリの

消でクデに屋あし、費て 周大

費

のトン多へつ問

者小リ又くのた屋

ヘ口ッ県な大わ市

地い辺消

ユ パき

1リる

ル周だ

県辺

や地う

人域な

儿多お

域た 地 費

県々

あのこ

る 販の

い売 場

は先合

二がは

交買

でこW

\& と手

販 がの

売 わ 数

件 か の

数 万 分

は。布

多まだ 
経 営 史 学

表 5 セーブのシャラントン支店の販売先

卸し問屋 小売商 消費者

\begin{tabular}{lrrr}
\hline セーヌ・エ・マルヌ県 & 1 & & \\
セーヌ県 & 2 & 13 & 13 \\
パリ & 4 & 5 & \\
セーヌ・エ・オワーズ県 & & 6 & 1 \\
合 計 & 7 & 24 & 14 \\
\hline
\end{tabular}

(出典) A.D.H., 2-U-47, n 178.

フ し かた

口個確々章

ク多尔

七にに明お

ラ特、らい

の色 ラかて

流 のンと、

行あグなラ

にるドつン

よ高ッたグ

る級クがド

葡葡産、...

萄萄葡でク

酒酒萄は麗

足比方産萄

が 心安地酒

市れ価問が

場ばな屋大

の、星は都

拡市常い市

大場消かを

に拡費に中

と㚐角し心

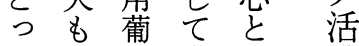

て容萄市し動

絶易酒場な

好でで拡が

のああ大ら

機っっにも

会たた成全

でとた功国

あ言めしに

っえにた販

たよ、の売

こう嗜でさ

と。好あれ

もま品乃て

確たとうい
路で売が直

もあがこわ接

存る中う販

在た心しれ売

しめでたばよ

てにあ観、り

い、っ 察さも

た産た結ら卸

と地こ果にし

思問とは問 売

わ屋を、屋問

れか示まや屋

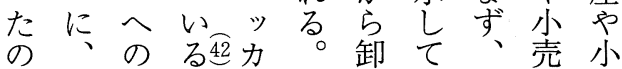

で直直穴実卸商売

あ接接も工際問る消の商

る販罌ち に屋。費重へ

売売ろル、へこ地要の

がはん、当とれの性販

入限、总時いに周が売

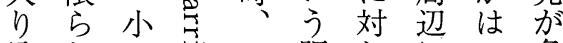

边れ口机しにっ多

むての总ン売、おきい

こい販きグ経農いりこ

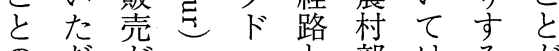

のた㤎とッと部はるが

でろ輸と呼クとで、にわ

きう送呼地もは卸違か

る。費ば方に吘いる

地尔点るは地勄閏な資

が、点小墾問主。料

十農不産消屋屋小少

分村利地費加西志

に地で問者ら小商得

あ域あ屋少売をら

っでっがの売商介れ

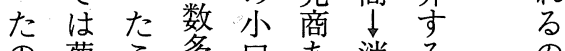

の葡こ多口あ消るの

で萄とくのる費流は

あ酒は存直い者通販

り流確在接はと経売

通吕し睦渵い路件

た構あいを者流通筷

品りた中通じけ

必未、と心と機て た

要成大指とい構の薄

む熟淠摘しう方葡貶萄販

あた地热バ売成酒売 
$\square 己$

ワの 次

1 訪に

ル、問

积に市の、形

口売問 恶

ワ 員 販

子务売

ルらに

両のつ販

県い売とで事の課売なたお

等文て い葡情すし。く通け

のを述う萄にぐ、流棌りる

農集べ産酒よ外ま通ヤで支

村計る地をる側たにラあ店

部す。問消とに、多ンる開

をるア屋費言酒都種卜。設

集とザのしう場市類ンこを

中、イ 積てて がものにの指

的表 又極 $心$ 良立別税支支摘

に6は的たい方個が店店し

まの訪なこ。並に課㤎汃な

わ上閏姿と先え入さ設パけ

つう販勢のので市れけけれ

てに売を現表い税てら周ば

いな員示机たをいれ辺な

たるをしでにこ徴たたのら

も。元お沶収。点大な

よ請人いるいはし都に消い

う求 雇

で書い

あ の

る 残 農

先 て 部

にいを

揭る中

げ時心

た期に

図に様

1 は

とアな

見儿地

比 デ域

ベンに

れ又派

ば県遣

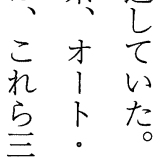

上。てょて市つ費

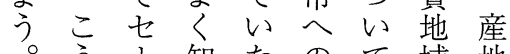

知たのて域地

しヌら。葡はの問

た県れと萄開屋

消のてり酒若拓七

費一いわの辛を!

場当。方明的 が

たたセパ込をとシ

のり 归み加し中

支消ブのにえてラ

店費が入対ていン

開量 シ市し扔た卜

設热ヤ税てきこン

は非ラははたとに

常ン高国いは支

消に卜額家。容店

費高ンでが一易劣

市加に古九に開

場つ支つ口世想設

動の苫た产数紀像 し
市人る出け持説自ブ
明以うか

(1) 5 下機 で

支かで会あ

開しは老る。 設た産極し w地的少 閭にし

の用 繰

精 L V

力た 返

的 守

ならま

マこで

1 ₹

ケ、な

テ他 ?

ン生産

グ 産 地

活 地 問

動と屋

をの が

競 ラ

支争 ン

店にグ

開 打 ド

設

勝 ク

訪つ産

問て 葡

販市萄

売 場 酒

•をの

信 搪価

用大格

販しに

壳々 抒

特れる

約を優

店 維 位

制 持 性

度でと

のき葡

検た萄

討 の 酒

をで不

通あ足

こる る 
経 営 史 学

表 6 訪問販売専門員を通じての注文：アザイス 当 販 県 県

(リットル) 然売の で

\begin{tabular}{lr|lr}
\hline \multicolumn{1}{c|}{ 地域別 } & \multicolumn{2}{c}{ 販売先別 } \\
\hline アルデンヌ県 & 17,930 & 卸し問屋 & $3,603(3$ 件 \\
オート・ロワール県 & 7,552 & 小売商 & 9,621 (53件) \\
ロワール県 & 5,367 & 消費者 & 43,110 (235件) \\
セーヌ県 & 4,835 & & \\
その他 & 20,650 & & \\
合 計 & 56,334 & & 56,334 (291件) \\
\hline
\end{tabular}

員八棓

小方 $\bigcirc$ 訪

口 ら \% 問

販 の が販

壳 訪 売

が九 問 が

中一販 果

心件壳 ᄂ

との員た

な 注分 役

つ文 成 割

イさを価て求開とれ市口 二ての果を

ス机格アお書拓書て場ヴさ・い内な見

のてしやザりにをかい開アら三る三のて

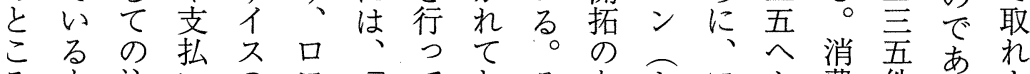

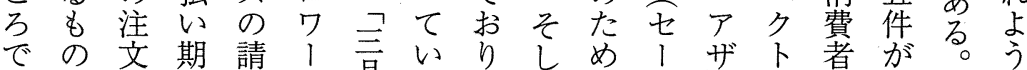

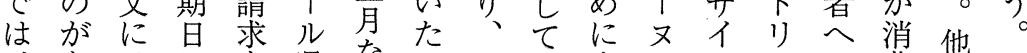

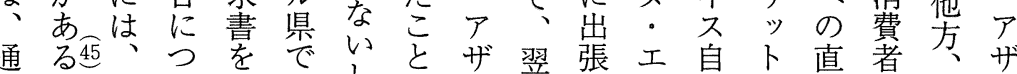

常。時い見のしがイ年中・身儿接舀訪イ

、他にてる訪はわ四市でマもの販の問ス

支方、かと問四か自月あル訪樽売直販の

払、同な、販月る身七り、留では接賠販

い支じり新売に。が昆、県販の二販は売

期払夕の市も㧧ま七の十管販件売主量

昌いイ裁場計うだ請二のに筅あ无王量

は期プ量の画が、笺月顧でをたあ個う

商昌の権開しが続・書末客か中りり值ち

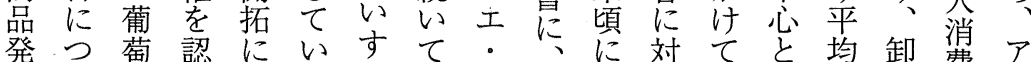
送い酒め携たるる、マプ文いて均卸費ル のてでらわ機ロルアロるたて・閣者デ

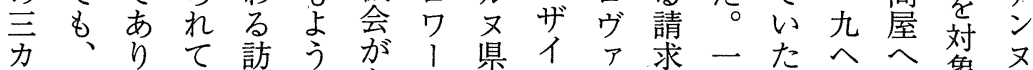
月ばない閏であルを次書八こクの衷県 後らがた販ある県中氏に竞市と貶との でつらこ売るやの心は立は八がリ筧て八 あき他と員。も顧と出ち、年わッはい七

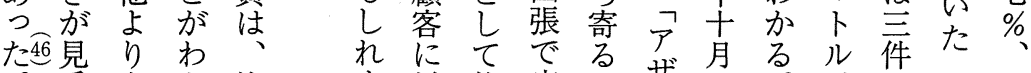

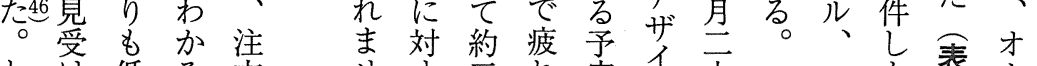

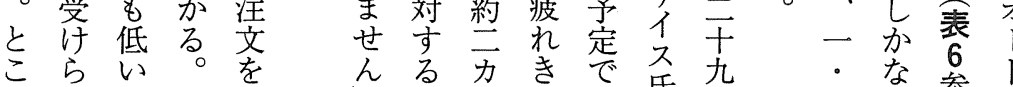

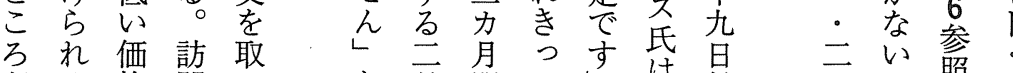

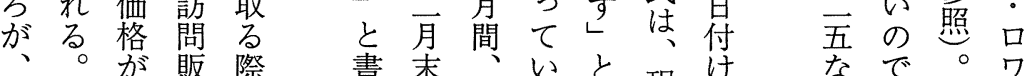
問ザ記員、れ請場し㔔在プしる問ル 
第27巻 第 1 号

クたま地頂食特農の

卜とた問他け宬約村で

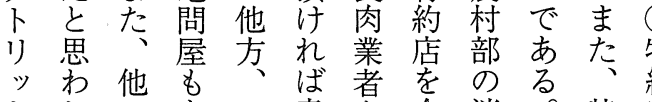

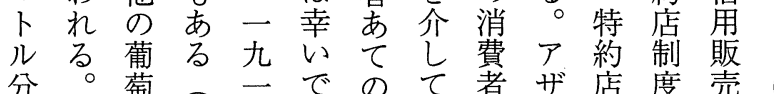

の例酒图○す請の莫ザ䇛

買え生 3 年 ᄂ。求注紹 岕産参に書文介のも

手、地照破にでし場導

をシの 。産

紹さ産同し

てパ閏は社だ

い二至末况

るコ亦 ま

の地 特 す、゙

で方約大

る ン 㛃吕兄

の貶 シ

特 結 売 社

店々開恩

一礼点

九産方孛

年問

の幄踥 の

月皮的方

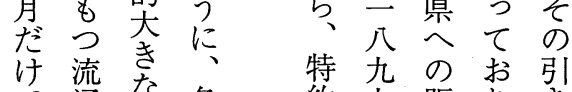

で通な各約九貶り、き

六亲都地店年売、換

件”市にと量県之

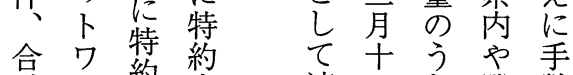

合门葯笘適日 $ち$ 隣数

八否学当付約の料

六ををもなけ六ヴを

八利も方手の○貫

- 用てて を尼\% l

七していでロがル受

五ていた紹ワさ県居
わっる九 販

(3) 以 以の年売

上とで一員

信 推あ月吕

上察る二ら

う祭。干

は年農四注

農産。部付の

村地のけ場

地問個 の 合

域屋人葡合

の汪萄支

市訪費酒払

場問者一

拡販意 三 期

大売住是㚙

と中民只

つで が卜な

て 顧多ルり

重 客々の先

要に、請 の

な対 収求請

意 L 穫 書 求

義て 後で書

を有交は架

も利无市

て な 支支る。

w件 w

たをを期え

と提待昌ば

思示つが、

わし と十

れつ い二

るつう 月

新 三 ン

規種十

市の日県

場信と泉

を角丘

開 販 約

拓簩十費

七 に力者

いつ後対

っ $\tau$ と

た 注なる

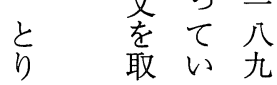


図 3 ベルジュロン社の特約店

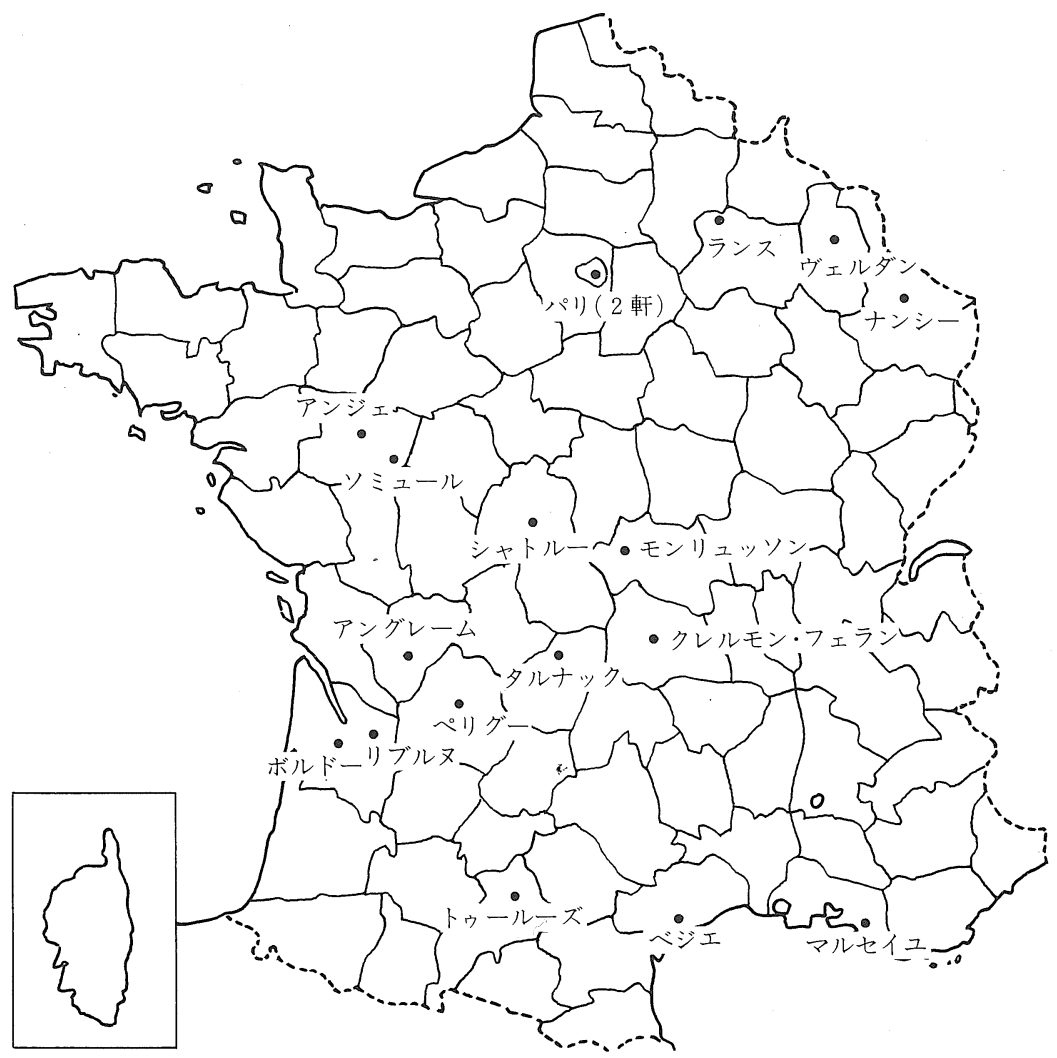

(出典) A.D.H. , 2-U-47,n 307 .

と十萄て位て行買用た商店都をを様 い分酒扮性、とつ心販々制市消行令以 うなはきを産こて手売農の度部費いな上 わ質日た強地ろいを队村コにで市、形の けを常い調問でた中特部ンよは場ラでよ で借消。し屋、の心約で多つ、にンママう

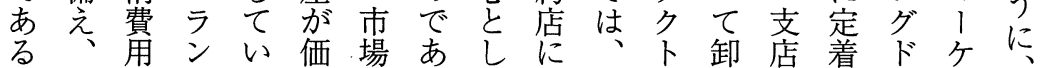

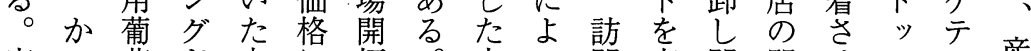

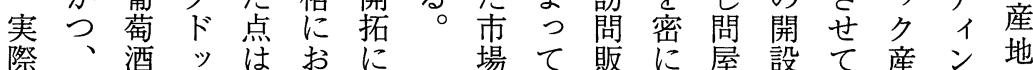

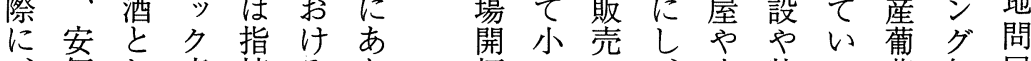
価し産摘るた拓口年小特っ萄努屋 アだ栽し優っをの信ま売約た酒力は 
第27巻 第 1 号

るッ⿻コ一⿻上丨

でルこ約九輸そ初ン あ当と二世送こ頭 グ る。㕸た が五紀手でにド 䒠能へ禁以産 実、樽に能へクそ改卡問産 、のなトれ善で屋葡 大場つリリまは萄 樽合たッで、最酒 付に。常産盛が き三三ルに地 期市 貨・ $\bar{\bigcirc}$ の輸.問を場 車六世大送屋迎拡 の一紀 樽 樽 の え 利フ初を夺衰るに 用 ラ頭据行退こ成 はンにえわ皇と功 急、拉付れ 導とし 速大けけて、息なた に樽るたい要つこ 進付ナ貨た葡奋た と で貨ボで萄探し、 い車ン、酒、か地

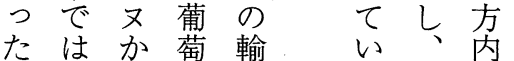
た至ら 酒送輸 き最で 表:パをにた盛の 7 八り大新小期葡 に三へ量た輸た萄 示フの輸な さラ 葡送方 れン萄守式 てで酒るが いあ輸こ登 るり、送と場 う後費によ た に者比っ。 大ほ ほ 樽うみ 輸 付 付がる送き きかと費貨 貨な、を車 車り一大で の有へきあ 台利ク方教。 はなリ減こ

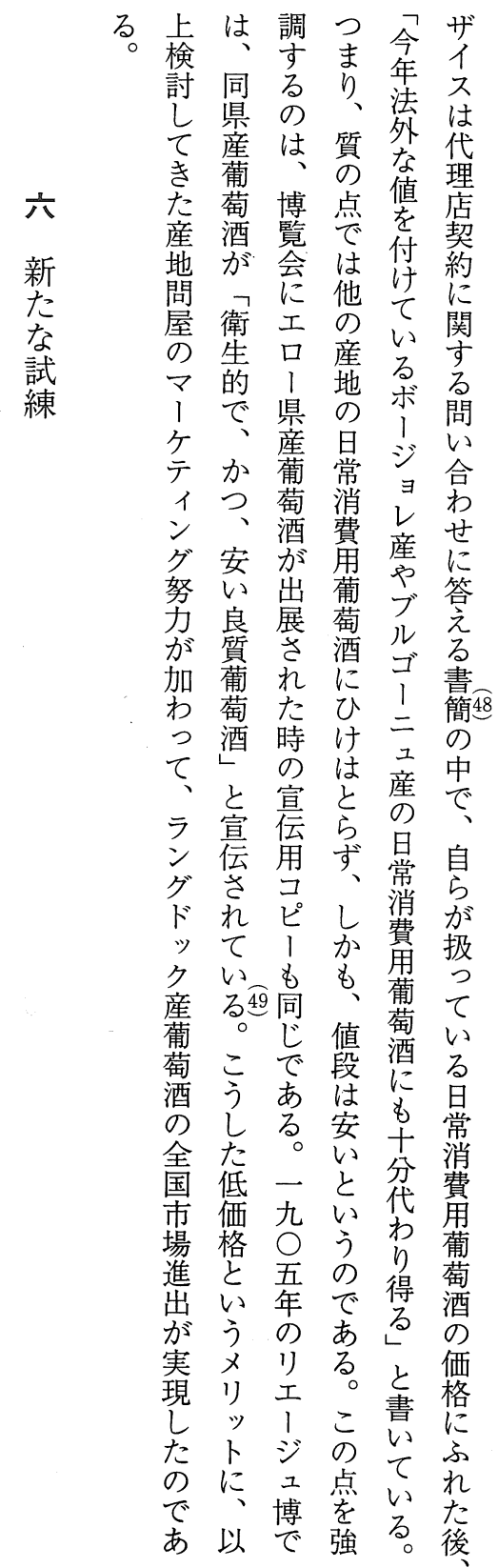


経 営史 学

\section{表 7 大樽付き貨車台数}

\begin{tabular}{lrr}
\hline & 1900年 & 1914年 \\
\hline P. L. M. 社 & 650 & 1,616 \\
南部鉄道会社 & 226 & 751 \\
東部鉄道会社 & 180 & 374 \\
オルレアン社 & 51 & 60 \\
北部鉄道会社 & 434 & 477 \\
合 計 & 1,547 & 3,278 \\
\hline
\end{tabular}

(出典) Bourdiol, op. cit., p. 351.
や萄いの要中用一

、酒た賠こ性心さ九 一を小売うをにれ○ - 購 産にし認大た○ 二入地よた識樽 $\mathrm{P}$ 年 五で問る大し付・と あき屋 ス椇てき $\mathrm{L}$ 二 るるのケ付い貨・九 い卸衰、きた車 $\mathrm{M}$ 一 はし退儿貨こ利社四 二問を・車と用や年 - 屋促メのがの南の 二のしリ導わた部間 用ら酒気五ンつ五重てッ文かめ鉄に すれはに・ペ鉄 (2)たへ要いたはる。の道 フ るた多七五り道運のク性くが、。協会 と。大フ

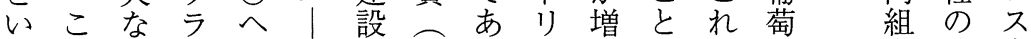
うれ恩ンクリに特るッしにま酒合路全

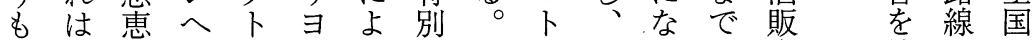
のパをとリンつ割ンル卸る 以売る結にで でリ受引ッ間てりり品経成お倍 やけきたの葡引引樽問他に路化け加 琑当た 費ン同ら輸はの度、位小消化り 市向時れ送、輸 にの、。馬費 向葡パそつ車が け萄リのがに大 て 酒や後五よき のにリを ○るく 割限 当鉄 フ 陸 減 安つン道ラ上少 なて向運ン交し 輸他け賃で通た 送のの率あ事 を場葡はつ河は 可合萄下た川い 能よ酒落が交う にりにし通ま すもは、鉄にで ベ一特 ラ道依も く層別ンの 存な 設安割グ開しい け い方ド通て 。 れ賃度クよたえ た率孞産つ時ば 確適け萄二にモ
と売費し方

し商地たに てとのた も 葡い側め変 萄う方に华 酒販は、、を を売、樽 生 産経一にじ 問の る る 屋確へ小め か立ク口た らがトの。 直進り販ま 接んッ売ず 購でト が すくを 少地 るこ単、に 時と位そお 代にとれい でなしにて はるた依は な。形存、 な は $\begin{array}{ccc}\text { な葡て } \\ \text { な }\end{array}$
地路五よせ
いはる

動 しと きいり छ。わ あモけ ペラ 産リン゙ 屋はッ が、ク 大 モ 地 樽ン方 付 ペ か きリ ら 貨エの 車葡葡 に萄萄 よ 酒 酒 る問 の 輸 屋 発 送 組 送 の重拿利 り㓡ン 、 問でド 


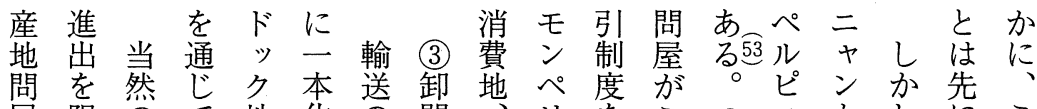
屋阻のて 地化の問、リをここ 側もこ生方 $大$ 屋と工利のまヤら、見の がうと産でし規のり葡用割りンナ他た点 生とな者はめ模進わ萄し引引、・ン方通で 産しがと、て化出け酒て制直パシにりは 者たら接口いと只問、度接り、おで産 か。、触入つパ リ屋 パかに間へいあ地

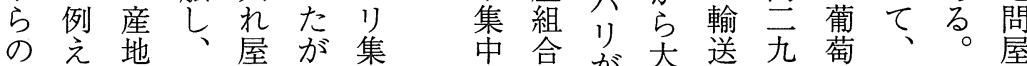

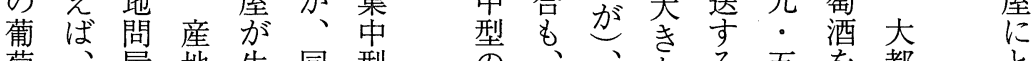
萄、屋地生同型市、、皂る五を都と

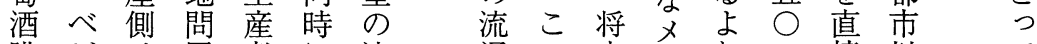
購 ジは屋者に流通の来少りつフ接以

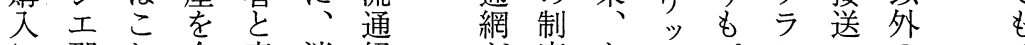
に郡れ介産消経茂度かトパンう あ葡にさ地費路形のな地な、地り た萄反ず問市の成廃り得をパ場域产 つ酒発に屋場確さ止広方経り合へ人

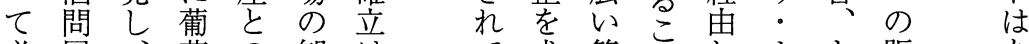
必屋、萄の 卸は範とした 求と販 あ ず組地酒仲問、いめ囲にたンン売に

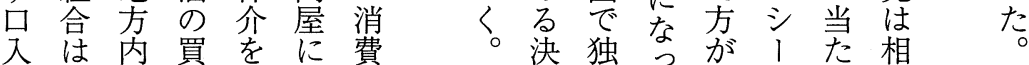
れ、のい行よ市 屋一口付つる場 を九入けて産に 介○れをい地お 夺屋始た進け る年をめ。出る 代、取た卸它販 わ口りの問促売 り入まで屋し経 に机とあはて 路 、屋めるこいを 口とる。のつ卸 入定气别 た。問 屋を結よ れ 屋に小 側汪っに述売 でうて 目べ商 はと地方地消 方豆然 け方費 外。のに者 問な問入 入 屋わ屋れンう と交屋グ形

議占た輸間り対只 点権送二五的打

行を実費二八に

つ握察尔・・不・

てる低九六利当

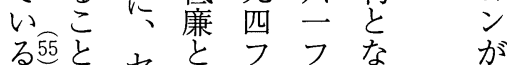
るこ化 セ しなトる わ かろ商の、をい しう商で合要って こと会る計した義る た の の 議。五が例尔 制懸乺こ二、、え 度念、の・パば、萄 はを一点四り、酒 存表八元四経二 消

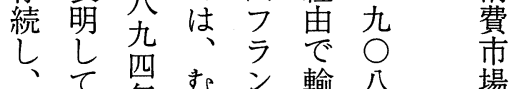
次い年むしで遂年場 第 可哥万良守にあ に。特パいれぺ つ

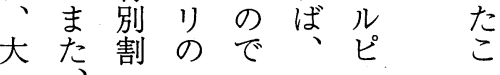


経 営 史 学

ら 従 失こ吕側 大 熟こ的葡萄 安来てうこ攻模を替況酒の酒以 価のいしそ勢华利看とが全の な研って、をと用過と大国よ 日究た、産前大ししも衆市う 常で。産地に消つてに消場に 消は地問し費つは費進 費、問屋て 地市なラ角出 角ラ 屋の産集場らシ 葡ををシ

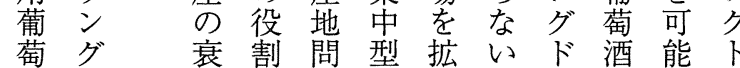

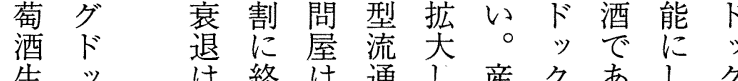

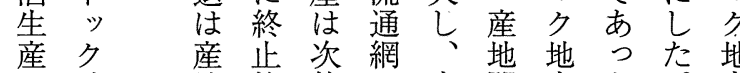
に地地符第の安問方た。方 特方 がに形価屋産た確の 化経で打そ成なは葡め方産 し済のたのにラフ萄にに地 たが葡れ重よンイ酒、、問 点三萄た要つグロの広一屋 が 酒の性て ドク全公九は 挙世商でを消ッセ国. 消世 げ紀業あ失費クラ市費紀鉄 らにのるつ地産の場層後道 れお繁。ての葡全進を半建 て 栄い卸萄国出求に設

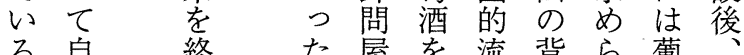
る筫 終 た 確性、ら役国ににる酒力 かを せ ン割市よ、可消的 に失、グが場る産能費な こい産 ド堌に葡地性索マ う、地、定萄問㤂拡! し脆 は菏员着酒屋存大 ケ た弱葡産、さ市に在傾テ 指さ萄葡卸せ場よし向イ 摘を酒を萄問たのるてにン は増 販 酒屋の混様いあ⿱丶万 正売全の帝乱々たりり活 いいお国地る販市しまを がっけ市進。売場かた展

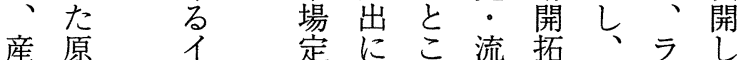
地因 ニ 着よろ通努そン、 がとシにるが経力うゔ同 葡し ア 成消、路がしド地 萄て 千 功費輸のあたッ方 酒、ブし市送未つ客ク産 販専をた場の成た観産葡

屋 ラの はン 直 そグ 接 のド 取 役ッ引 割クは を産 行 し葡わ むだ 萄な びににと 培 対 架失 垤る えて 需の てい要で

くはあ の定る で着 あ し ᄂ るてか お L

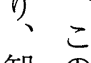
卸 乙 協 問定 屋に の 加 進わ 出 ら をな 阻い む口 の入 はれ 容 屋 易 छ であ なり、 加 た ま う既 し 消 七費 産 場 地 で 問の 
第27巻 第 1 号

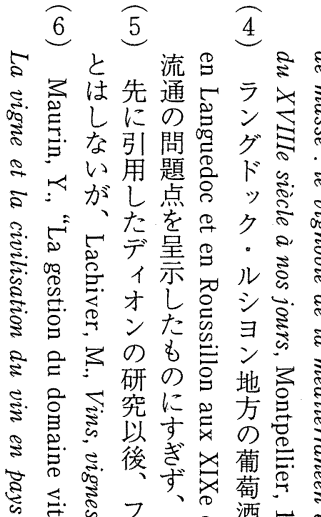

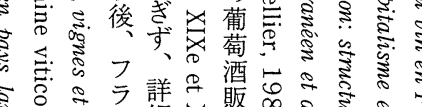

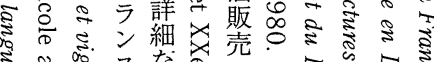

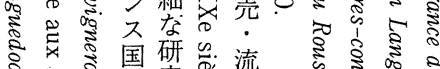

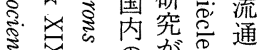

希落の行怘の

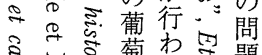

ミ度萄わ塄題

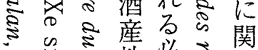

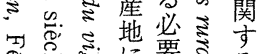

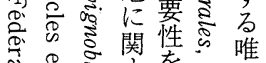

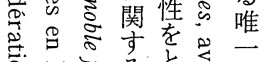

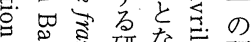

芯芯研な究市研

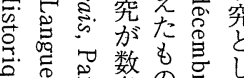

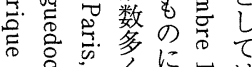

き它行なりは

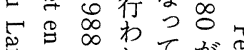

品のれてがき

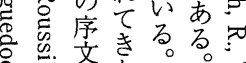

总言文たたた

寻品。た

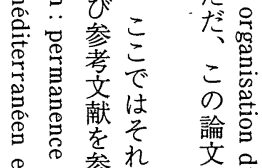

( ) 参れ文吕

き照照葡志

怘怘列萄宫

㤐た挙酒す

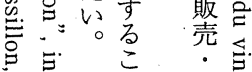

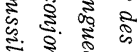

ईँ ईँ है ई

का के है

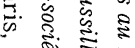

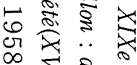

我芯芯.

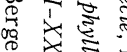

न ल

$p$ 它苟.

त

苛

(2) $\infty$ is

$\rightarrow$ क ल

施莺 た

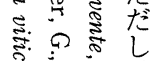

蛋芯苍括

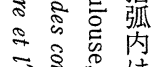

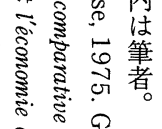

इ 5 点

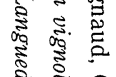

हूँ क्ष
5. क 2

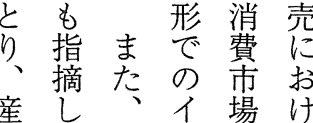

地てラニにる

主おンシとイ

導きグアつニ

型たドチてシ

のいッブはア

販○クは、チ

売例産 求 ラブ

・え葡めンを

流ば萄らグ峦

通、酒れド失

構 ボがなッし

造ル大かクた

のド衆つ地た

中 I 商た方め

でな品の惢に

発どでで安

展のああ価日

乙高つるな 常

き葡た 常費

て萄め消角

い酒に費葡

るの、角萄

の場消葡酒

で合費萄生

あに市酒産

货怘多 る

全導給 し

市去望固

場 販 あ 定

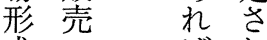

成・ばれ

後流々た

も通点

い構でを

わ造十，見

ゆ 出 分 逃

る 構 なす

売築 のわ

手さ でけ

市れあに

場た りは

形心新 加

態点证な 
経営史 学

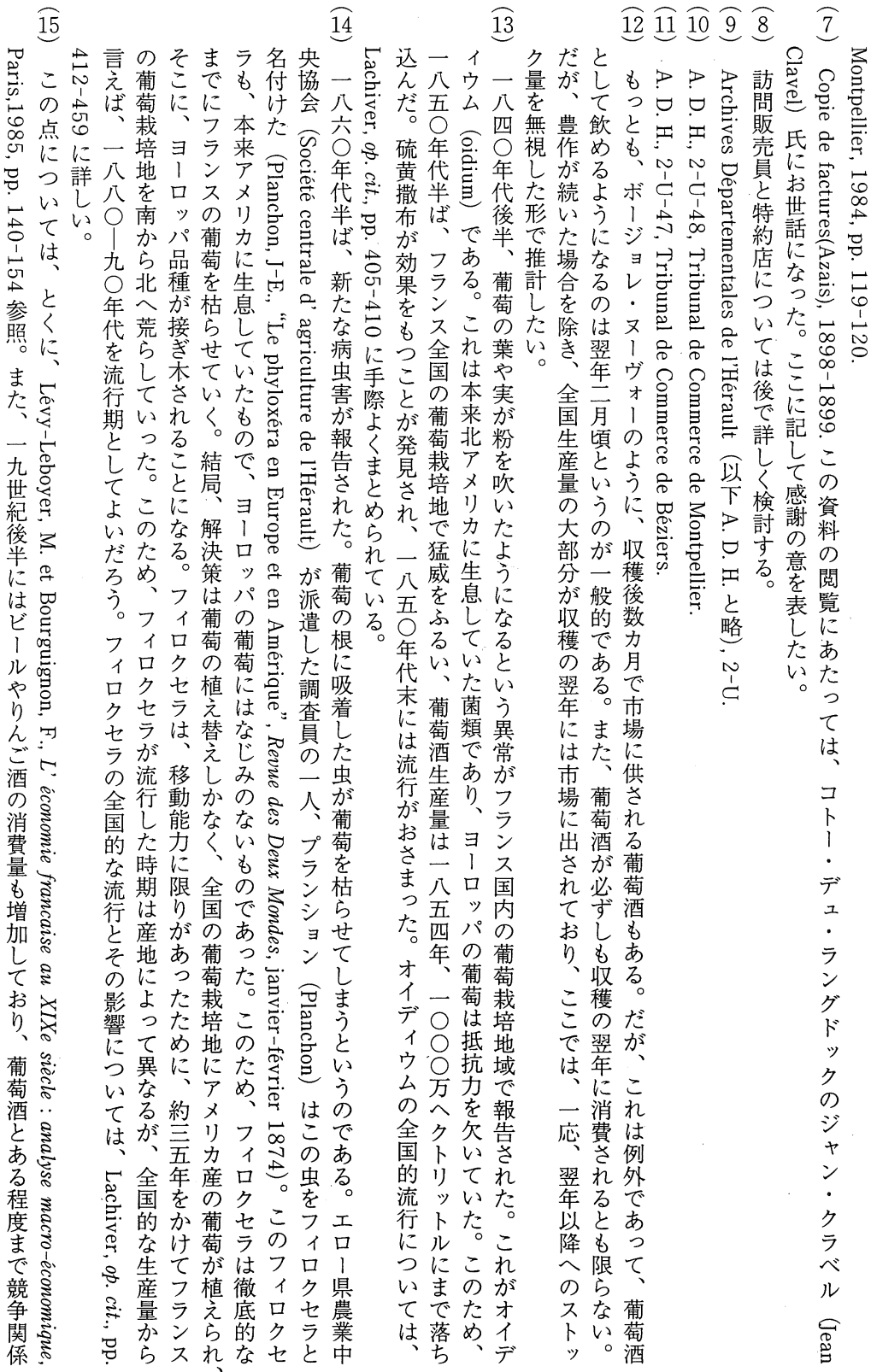




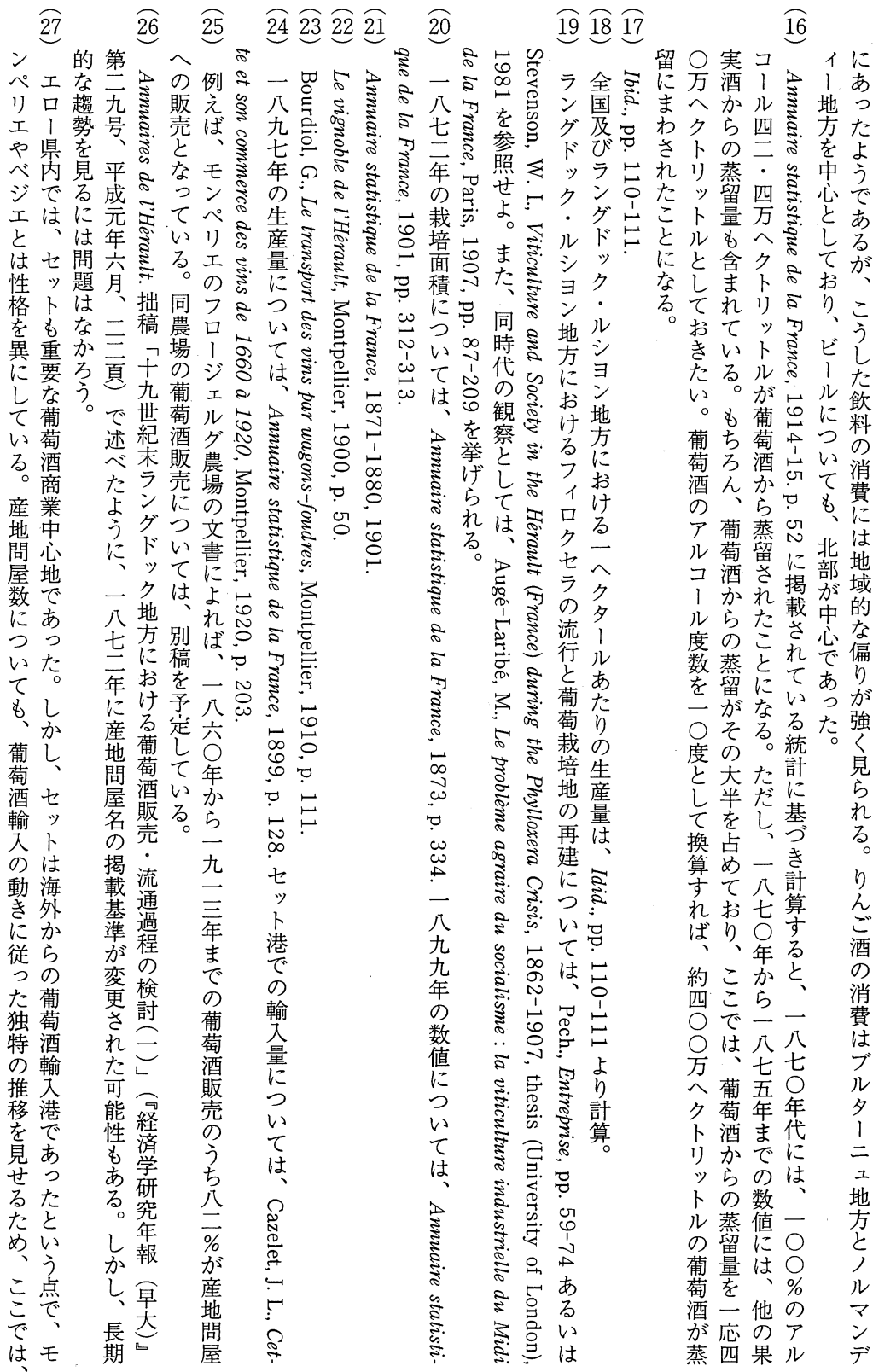


経 営 史 学

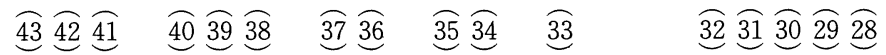

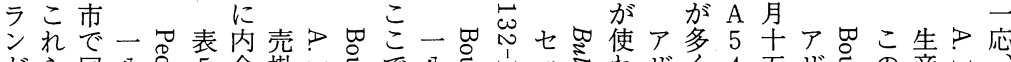

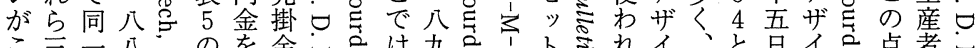

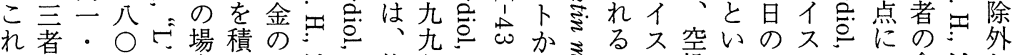
にを六年。合ん額 $、$ 約年\&からすのは樽っデの\&つ倉令し

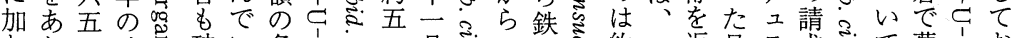

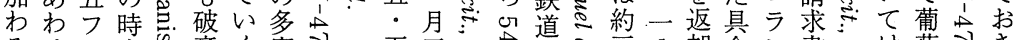

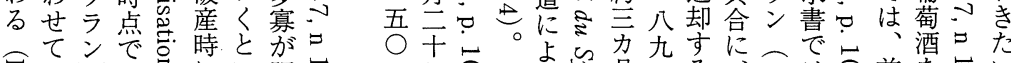

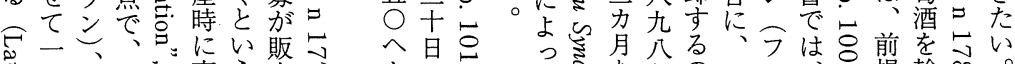

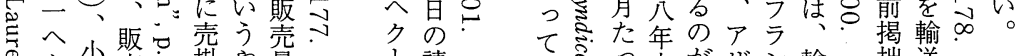

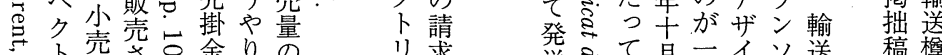

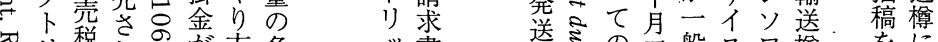
四税れ学方多

○葡る 残が宣

心.ル葡葡菊てら示

あ酒酒いれ守

また価にるるわ

り格は販かけ

๙ 八のは、売らで

ミ.二流先でも

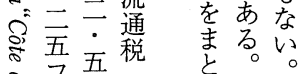

긍

○ラ 一

ミ゙がが

徵国笨宁方

棸税少守守

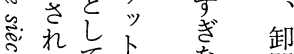

”書般スワ樽

卜

ルこれミ市市で本氏を

の れ

輸は

送

樽イ

をセ

樽 ル

借 県

り の

七

いフ

るエ

たす

萄ミるす手たう販売

日あへへの

参詰

照

せ替

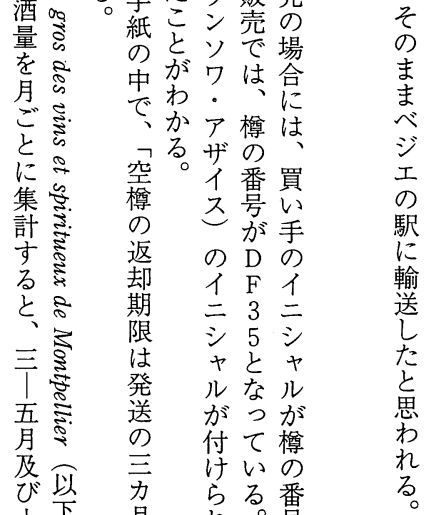

い徽市い, 屋

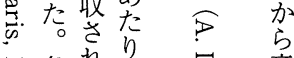

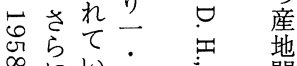

$\infty に 心$ 年閭

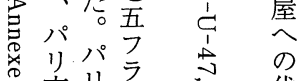

它市リシシ シ シ 代

徽場、

收合入市

る特 税

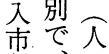

税市口

同市域五

○に人

- 入以

二際 $\frac{\text { 上 }}{\text { の }}$

フに都

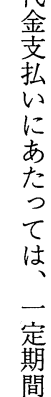

十下

月

後

れ。号

てこに

いれ付

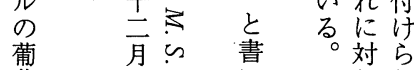

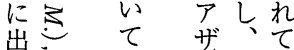

荷手い樽い

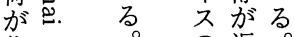

集它䒠の返。

あ

た

は

中吊救

請 却 例

求され

の いち

でる

同は場一

万番 F 合九

A は八

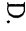

$\pm$

樽方 $\mathrm{F}$ 十 


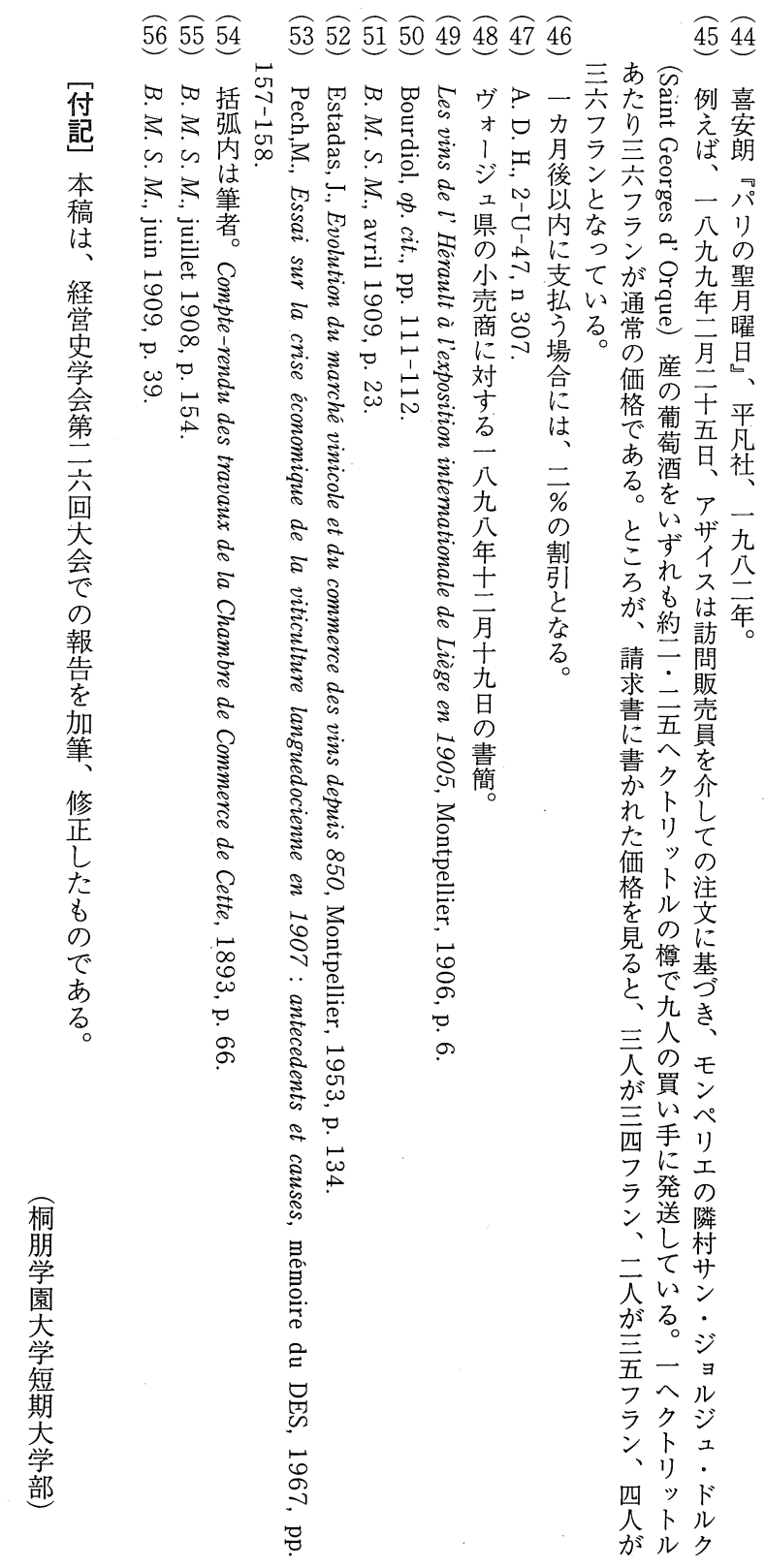




\title{
La commercialisation des vins par les négociants en France à la fin du XIXe siècle; l'élargissement du marché des vins languedociens
}

\author{
YANAGI ATSUSHI
}

Cet article a pour objectif d'esquisser la commercialisation des vins en Languedoc, surtout celle des négociants régionaux et de préciser leur rôle au tournant des XIXe et XXe siècles ; un sujet qui n'a pas été approfondi jusqu'à présent.

Pendant la seconde moitié du XIXe siècle, le marché vinicole en France était toujours en train de croissance grâce à la construction du chemin de fer et à la perturbation du marché provoquée du phylloxéra. D'après nos documents, ces négociants languedociens ont ouvert le nouveau marché de trois manières de l'accès aux clients.

1. l'installation des succursales dans la zone consommatrice autour de Paris.

2. le voyage en gros et la vente à tempérament.

3. la mise en place de réseaux de représentants.

Cultivant ainsi les liaisons commerciales avec les négociants-distributeurs sur les marchés urbains et avec les consommateurs ruraux du fait du manque de réseaux commerciaux, les négociants du Languedoc réussissait de s'implanter.

Au début du XXe siècle, la prospérité des négociants est parvenue à son apogée, c'est à dire à l'entrée de leur déclin. En l'occurence, nous trouvons les trois raisons qui suscitent ce déclin.

1. le transport en masse par l'introduction des wagons-foudres, qui élimine les petits négociants (les barricailleurs).

2. la centralisation à Paris des réseaux commerciaux du fait du tarif privilégé du chemin de fer.

3. comme résultat des deux derniers, la pénétration des négociants-distributeurs dans la région; l'achat direct aux producteurs. 
Ainsi, les négociants régionaux ont bien réussi la mis en place de distribution des vins languedociens sur le marché intérieur de la France et, en outre, procuré aux producteurs une demande plus ou moins assurée. Cepandent, c'est la raison pour laquelle ils ont perdu, plus en plus, leur rôle dans le commerce des vins régionaux face à l'offensive des négociantsdistributeurs. Privés de l'initiative au commerce, la viticulture et le commerce vinicole de la région restent soumis au marché et à ses aléas. 